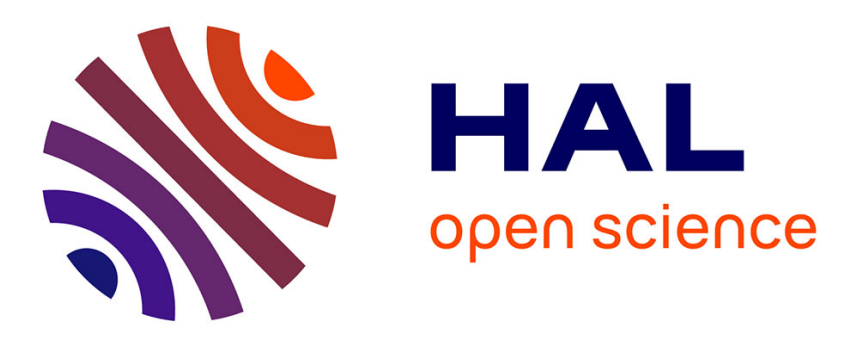

\title{
Magnetic stratigraphy of Kimmeridgian-Aptian land sections from Umbria-Marche (Italy): New details on the M-polarity sequence
}

F. Speranza, S. Satolli, Emanuela Mattioli, F. Calamita

\section{- To cite this version:}

F. Speranza, S. Satolli, Emanuela Mattioli, F. Calamita. Magnetic stratigraphy of KimmeridgianAptian land sections from Umbria-Marche (Italy): New details on the M-polarity sequence. Journal of Geophysical Research, 2005, 110, pp.B12109. 10.1029/2005JB003884 hal-00193735

\section{HAL Id: hal-00193735 \\ https://hal.science/hal-00193735}

Submitted on 13 Feb 2021

HAL is a multi-disciplinary open access archive for the deposit and dissemination of scientific research documents, whether they are published or not. The documents may come from teaching and research institutions in France or abroad, or from public or private research centers.
L'archive ouverte pluridisciplinaire HAL, est destinée au dépôt et à la diffusion de documents scientifiques de niveau recherche, publiés ou non, émanant des établissements d'enseignement et de recherche français ou étrangers, des laboratoires publics ou privés. 


\title{
Magnetic stratigraphy of Kimmeridgian-Aptian sections from Umbria-Marche (Italy): New details on the $M$ polarity sequence
}

\author{
Fabio Speranza, ${ }^{1}$ Sara Satolli, ${ }^{2}$ Emanuela Mattioli, ${ }^{3}$ and Fernando Calamita ${ }^{2}$ \\ Received 13 June 2005; revised 14 September 2005; accepted 3 October 2005; published 23 December 2005
}

[1] The magnetic stratigraphy of the Maiolica and Calcari ad Aptici pelagic limestones is documented from four Umbro-Marchean land sections (Italy). The overall biostratigraphic age of the sampled strata encompasses the whole Kimmeridgian-Lower Aptian. The data were gathered from two new sections (Arcevia, Contessa) and by resampling more densely than in the past two additional classical sections (Bosso, Gorgo a Cerbara). A detailed record of the polarity chrons M21n-M14 and M9-M0 was derived, and no difference was observed with respect to the sequence of $\mathrm{M}$ polarity chrons inferred from oceanic magnetic anomalies. Barely measurable remanent magnetization from chron M14 to M10n at Contessa concurred with previous evidence from Bosso, indicating that the Maiolica from Umbria-Marche is characterized by a "recording gap" during chrons M14n to M11, possibly due to diagenetic magnetite dissolution related to the Late Valanginian carbon isotope event. At Arcevia and Bosso, the boundary between Maiolica and Calcari ad Aptici occurs at the top of chron M19n and in the upper part of chron M20n, respectively, showing that the onset of Maiolica sedimentation may be diachronous by 1.5-2 Myr along the Umbria-Marche domain. Arcevia is the most expanded Mid-Upper Tithonian land section documented so far. Here, the subchrons M20n-1 and M19n-1 are found to represent $3.2 \%$ and $10.1 \%$ in time of chrons M20n and M19n, respectively. Evidence is also provided for a reversal excursion occurring within the M20n-1 subchron. At Bosso, an excursion and a reversal excursion were found within chrons M16n and M16, respectively.

Citation: Speranza, F., S. Satolli, E. Mattioli, and F. Calamita (2005), Magnetic stratigraphy of Kimmeridgian-Aptian sections from Umbria-Marche (Italy): New details on the M polarity sequence, J. Geophys. Res., 110, B12109, doi:10.1029/2005JB003884.

\section{Introduction}

[2] The pelagic sequences exposed in the Umbria-Marche Apennines (Italy, Figure 1) have proven for over 30 years to be faithful recorders of the polarity of the geomagnetic field from Early Jurassic to late Tertiary times. Pelagic (mainly calcareous) sedimentation developed over HettangianSinemurian peritidal shelf carbonates, and continued for the whole Mesozoic and early Tertiary. Though the sedimentation rates are not extremely high $(5-10 \mathrm{~m} / \mathrm{Myr}$ on average) they are normally greater than those observed in coeval strata (yielding magnetostratigraphy) from France, Spain, and northern Europe, which revealed the correlation between polarity magnetozones and ammonite biozonation for the Mesozoic. Moreover, the pelagic strata from Umbria-Marche host a very stable remanent magnetization, and no regional phenomenon of magnetic overprint has ever been docu-

\footnotetext{
${ }^{1}$ Istituto Nazionale di Geofisica e Vulcanologia, Rome, Italy.

${ }^{2}$ Dipartimento di Scienze della Terra, Università di Chieti, Chieti, Italy.

${ }^{3}$ Centre de Sciences de la Terre, Université Claude Bernard Lyon 1, Villeurbanne, France.

Copyright 2005 by the American Geophysical Union. 0148-0227/05/2005JB003884\$09.00
}

mented. Combined biostratigraphic and magnetostratigraphic analyses of the Meso-Cenozoic sequences from Umbria-Marche provided during the 1970s and 1980s a spectacular and independent validation of the sequence of polarity chrons as inferred from oceanic magnetic anomaly profiles [Alvarez et al., 1977; Lowrie et al., 1980, 1982; Lowrie and Channell, 1984; Lowrie and Alvarez, 1984; Cirilli et al., 1984]. Moreover, biostratigraphic analyses have allowed the correlation of several biostratigraphic events, and hence geologic stage boundaries, to magnetic polarity chrons.

[3] The correlation of ammonite, nannofossil, calpionellid, planktonic foraminifera and radiolarian events to the $M$ sequence polarity chrons has been satisfactorily obtained in Umbria-Marche by studying the Maiolica Formation, an Upper Tithonian to Lower Aptian thin-bedded calcareous succession. Good magnetostratigraphic records of chrons M20n to M14n [Lowrie and Channell, 1984; Cirilli et al., 1984; Housa et al., 2004] and M11 to M0 [Lowrie et al., 1980; Lowrie and Alvarez, 1984; Cirilli et al., 1984; Channell et al., 1995a, 2000] were reported for the Umbria-Marche Maiolica limestones. Conversely, no Maiolica section from Umbria-Marche has magnetostratigraphically documented so far the sequence of M14n to M11 chrons. 


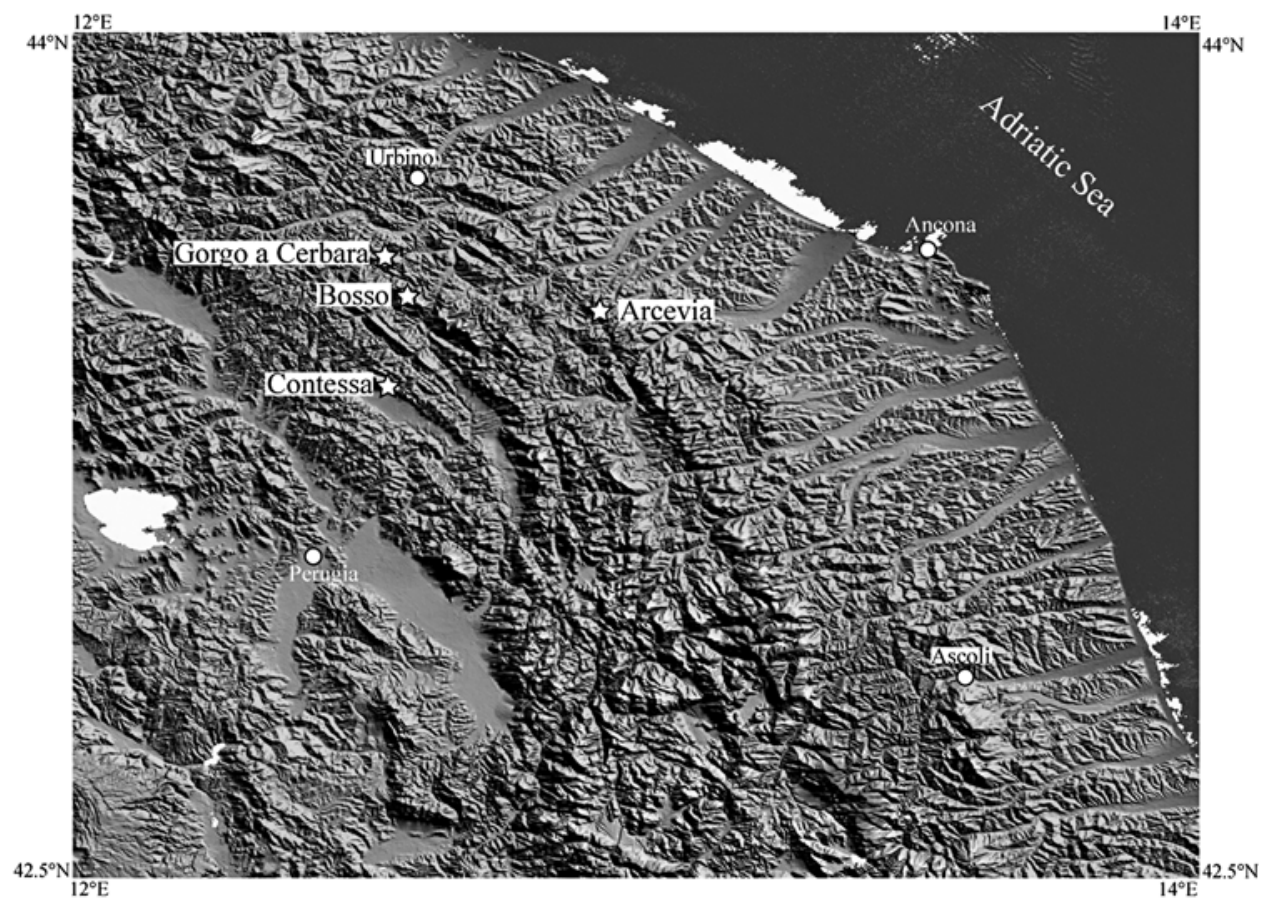

Figure 1. Digital elevation model of the Umbria and Marche regions (northern Apennines, Italy), and location of the studied sections. Digital elevation model data were downloaded from the U.S. Geological Survey's EROS Data Center, NASA Jet Propulsion Laboratory, California Institute of Technology.

[4] Here we provide a new detailed magnetic stratigraphy (sampling spacing of $\sim 50 \mathrm{~cm}$, or less) of four UmbriaMarche sections, which (taken together) encompass the whole Kimmeridgian-Lower Aptian time span: Arcevia, Bosso, Contessa, Gorgo a Cerbara. Besides the Maiolica limestones, also the underlying Kimmeridgian-Tithonian Calcari ad Aptici limestones were sampled. Our aim was to document in greater detail than in the past the characteristics of the geomagnetic field during the upper part of the $\mathrm{M}$ polarity sequence, as recorded in the Umbria-Marche limestone strata. The newly sampled sections were selected (1) to try to extend back in time (for chrons older than M20n) the correlation of the M polarity sequence to magnetozones from Umbria-Marche (Arcevia) and (2) to document a Maiolica section displaying a clear record of chrons M14n to M11 (Contessa). Moreover the classical Bosso and Gorgo a Cerbara sections, were resampled more densely than in the past, in order to gather a complete, detailed magnetic polarity record for the whole Kimmeridgian-Lower Aptian time span.

\section{Sedimentary Characteristics of the Maiolica and Calcari ad Aptici Limestones}

[5] The studied limestones belong to the well-known Umbria-Marche pelagic sequence, developing after midSinemurian along the African-Adriatic passive margin due to a regional-scale extensional episode drowning a preexisting peritidal carbonatic shelf [Morettini et al., 2002]. The pelagic succession is mainly calcareous, though at some intervals clays and cherts predominate. The Sinemurian extensional tectonics left some fragments of HettangianSinemurian shelf carbonates ("Calcare Massiccio") as uplifted horsts within the Umbria-Marche basin ("pelagic carbonate platforms" according to Santantonio [1993]). Here the Sinemurian-Tithonian succession is condensed or lacking, and is capped by the Upper Tithonian-Lower Aptian "Maiolica" limestones, which were deposited ubiquitously all over the basins and the uplifted horsts. In the present paper, the magnetostratigraphic investigations are focused on the Maiolica Formation and on the underlying "Calcari a Saccocoma ed Aptici" Formation (hereinafter referred to as Calcari ad Aptici).

[6] The Maiolica is uniformly made up by thin-bedded fine-grained white to gray limestone strata containing gray and black chert nodules and layers. Its thickness may vary from $\sim 100 \mathrm{~m}$ (where it overlies the preexisting horsts), to $400-500 \mathrm{~m}$ in the deeper basinal areas. Biostratigraphic data from Maiolica were provided by documenting nannofossil [Lowrie et al., 1980; Bralower et al., 1989; Coccioni et al., 1992; Cecca et al., 1994a; Channell et al., 1995a, 2000], calpionellid [Micarelli et al., 1977; Cirilli et al., 1984; Channell and Grandesso, 1987; Housa et al., 2004], planktonic foraminifera [Coccioni et al., 1992; Cecca et al., 1994a], radiolarian [Baumgartner, 1987], but also rare ammonite finds [Cecca et al., 1994a, 1994b; Channell et al., 1995a; Baudin et al., 1997].

[7] During the last 30 years, several magnetostratigraphic investigations in the Maiolica from Umbria-Marche have shown that the magnetic remanence is very weak, but, where measurable, yields a very stable magnetic signal. The magnetic mineralogy is dominated by magnetite [Channell and McCabe, 1994], and magnetization is thought to have been acquired during early diagenesis, within $\sim 10-20 \mathrm{~cm}$ below the sediment-water interface [Channell et al., 1995a]. The pattern of retrieved magneto- 
zones has proven to nicely mirror the sequence of $\mathrm{M}$ polarity chrons as inferred by oceanic magnetic anomaly analysis, and it has been shown that Maiolica limestones were deposited in the studied sections from chrons M20n to M0 [Lowrie et al., 1980; Lowrie and Channell, 1984; Lowrie and Alvarez, 1984; Cirilli et al., 1984; Channell and Grandesso, 1987; Channell et al., 1995a, 2000; Housa et al., 2004].

[8] The Calcari ad Aptici Formation shows variable facies and thickness. Generally, it is formed by thin-bedded greenish limestones with black-gray cherts containing ammonite aptychi as macrofossils. Both fine-grained limestones and calcarenites are observed, and the color (of both limestones and cherts) may become red or reddish. The thickness normally varies from 0 (in correspondence with the horsts) to $\sim 20 \mathrm{~m}$, in the most expanded sections observed so far. Biostratigraphic data (predominantly from ammonites, but also from radiolarians) indicate an age comprised between Early Kimmeridgian to Late Tithonian [Cecca et al., 1987; Baumgartner, 1987; Morettini et al., 2002]. Magnetostratigraphic data were gathered from two sections (Bosso and Sentino [Lowrie and Channell, 1984; Channell et al., 1984; Housa et al., 2004]), but a convincing correlation with the $\mathrm{M}$ sequence polarity chrons of the Upper Jurassic has not been observed so far.

[9] The four studied sections are exposed within the cores of NW trending anticlines in the Umbria (Contessa) and Marche (Arcevia, Bosso, Gorgo a Cerbara) regions (Figure 1). These structures are a part of the external northern Apennine belt [Consiglio Nazionale delle Ricerche, 1991] and formed after late Messinian-early Pliocene shortening episodes.

\section{Methods}

[10] In the four sections, an average sampling spacing of $50 \mathrm{~cm}$ was adopted, reduced to $30 \mathrm{~cm}$ at the bottom of the Bosso section, where condensed sedimentation was expected in the Calcari ad Aptici strata. Further "ad hoc" paleomagnetic sampling was addressed to layers showing large virtual geomagnetic pole (VGP) departures $\left(>45^{\circ}\right)$ within the same magnetozone and/or documenting the details of short duration ( $\sim 100 \mathrm{kyr}$ or less) subchrons, in beds characterized by expanded sedimentation. A total number of 861 samples were collected from the four sections, by drilling 2.5 -cm-diameter cores using a petrolpowered portable drill cooled by water. The cores were oriented in situ before extraction by a magnetic compass, corrected to account for the mean magnetic declination of the geomagnetic field in Umbria-Marche during the year $2004\left(\sim+2^{\circ}\right.$ according to Istituto Nazionale di Geofisica e Vulcanologia [2001]). Subsequently, the cores were cut into standard cylindrical specimens and their remanent magnetization was measured in the shielded room of the paleomagnetic laboratory of the Istituto Nazionale di Geofisica e Vulcanologia (Rome) by a $2 \mathrm{G}$ DC-Squid cryogenic magnetometer. For the Maiolica limestones, alternating field (AF) cleaning effected by three coils in-line with the magnetometer was systematically adopted, using 15 demagnetization steps per sample, up to a 70-mT maximum AF field. Twin samples from some of the Maiolica cores were also thermally demagnetized in 9-12 steps, in order to check the coherence of the paleomagnetic behavior during cleaning. As a rule, the Calcari ad Aptici samples were always thermally demagnetized in 9-12 steps, but twin samples from Arcevia cores were also AF cleaned in 15 steps.

[11] Demagnetization data were plotted on both orthogonal demagnetization diagrams [Zijderveld, 1967] and on equal-area projections, and the magnetization components were isolated by principal component analysis [Kirschvink, 1980]. The VGP latitudes of the characteristic magnetization components (ChRMs) from each sample with respect to the Earth's rotation axis were evaluated by calculating the angles between the individual VGPs and the mean paleomagnetic pole of the section [e.g., Lowrie et al., 1980]. The reversal test (according to McFadden and McElhinny [1990]) was performed on the ChRMs from each studied section.

[12] In order to frame the magnetostratigraphic data into the geomagnetic polarity timescale (GPTS), the succession of our magnetozones was systematically compared to the timescale and polarity chron nomenclature from Gradstein et al. [1994] (hereinafter GRAD94). The duration of chrons from GRAD94 is similar to that from the updated scale from Gradstein et al. [2005], except for chron M0 (0.6 versus $0.39 \mathrm{Myr}$, respectively). Therefore, at Gorgo a Cerbara the sedimentation rate during chron $\mathrm{M} 0$ was inferred by using both scales. At Arcevia, the duration of the subchrons M20n-1 and M19n-1 (as derived by polarity subzone thickness) was also compared to the GPTS from Channell et al. [1995b], which was computed using a different oceanic magnetic anomaly block model to GRAD94.

[13] For the Bosso section, we considered the biostratigraphic data from Micarelli et al. [1977], Baumgartner [1987], Channell and Grandesso [1987], Bralower et al. [1989], Channell et al. [1995a], and Housa et al. [2004]. At Gorgo a Cerbara, the biostratigraphic evidence from Lowrie et al. [1980], Coccioni et al. [1992], Cecca et al. [1994a; 1994b], and Channell et al. [1995a, 2000] was used. In the Contessa and Gorgo a Cerbara sections we also sampled the uppermost Hauterivian ammonite "Faraoni" guide level [Cecca et al., 1994b], which was correlated to the midlower part of chron M5n (at Bosso and Gorgo a Cerbara) by Channell et al. [1995a].

[14] The nannofossil content was determined for core cuttings from the whole expanded Calcari ad Aptici section (43 $\mathrm{m}$ of thickness) at Arcevia, and for the lowermost $13 \mathrm{~m}$ of Maiolica exposed at Contessa. Smear slides for nannofossil analysis were prepared by spreading a small amount of rock powder onto a cover slide, which was permanently mounted on a slide by Rhodopass. Slides were studied in a polarizing optical microscope, with a magnification of 1000X. On average, 200 specimens were counted for each sample in a variable surface of the slide for Arcevia (0.008 to $0.08 \mathrm{~cm}^{2}$ ) and only a mean of 70 specimens/sample for Contessa ( 0.06 to $0.12 \mathrm{~cm}^{2}$ of the slide) according to the richness of the different samples. For Arcevia, with a mean of 200 counted specimens/sample, a species rare in the assemblage (e.g., representing a proportion of $1 \%$ ) has a probability of about $15 \%$ of not being detected [Hay, 1972]. This means that there are good chances of finding even rare species (i.e., marker species). The low number of nannofossils counted in Contessa samples, that are much poorer than those from Arcevia, did not allow us to be sure about 
the detection of rare marker species. However, the relatively important surface analyzed for each slide increased the probability of the recovery of rare taxa, and compensated the low number of nannofossils that could be counted. Preservation has been visually evaluated on the basis of etching and/or overgrowth effects observed on nannofossils [Roth, 1984]. Three preservation classes were established: (1) poorly preserved assemblages, with strong evidence of etching and/or overgrowth; (2) moderately preserved, and (3) well-preserved assemblages, where etching/overgrowth is limited or absent.

\section{Paleomagnetic Sampling and Results}

\subsection{Arcevia}

[15] The Arcevia section is located just north of the village of Arcevia $\left(43^{\circ} 30^{\circ} \mathrm{N}, 12^{\circ} 56^{\prime} \mathrm{E}\right)$, where Maiolica and Calcari ad Aptici beds in stratigraphic continuity are exposed within an active quarry cut by several quarrying terraces (Figure 2a). Strata dip by $\sim 40^{\circ}$ to the SW, on average. The Calcari ad Aptici Formation shows an apparent thickness of $\sim 55 \mathrm{~m}$, which is about three times that observed in other deep basin sections (Bosso, Sentino), though some faults possibly producing tectonic duplication are observed. It consists of fine-grained greenish limestones with beds $10-80 \mathrm{~cm}$ thick containing frequent ammonite aptychi, intercalated with gray-black chert layers and nodules.

[16] Oriented cores with an average spacing of $\sim 50 \mathrm{~cm}$ were drilled along two superimposed subsections (Figure 2a). In the upper stratigraphic subsection we sampled $46 \mathrm{~m}$ of Maiolica and the underlying $26 \mathrm{~m}$ of Calcari ad Aptici. The upper part of the Maiolica (at $15 \mathrm{~m}$ from the top) is cut by a fault with unknown displacement. Conversely, at the Maiolica-Calcari ad Aptici boundary, the $1-\mathrm{m}$ offset of a fault displacing this stratigraphic boundary could be easily constrained. All this Maiolica-Calcari ad Aptici subsection was sampled during quarry excavation, but it was afterward covered by soil, so that unfortunately it is now no longer exposed.

[17] The lower stratigraphic subsection was sampled along a higher quarrying terrace (Figure 2a), which it is still exposed and will not be modified in the future, according to the quarry workers. Here we sampled $34 \mathrm{~m}$ of Calcari ad Aptici. A stratigraphic overlap of a few meters was apparent for the two subsections, but it was not possible to perfectly follow a laterally equivalent Calcari ad Aptici bed. The lower stratigraphic subsection is cut by two faults with unconstrained displacements at 28 and $12 \mathrm{~m}$ above the subsection bottom.

[18] In the Maiolica samples, the remanence was very weak $(10-120 \mu \mathrm{A} / \mathrm{m})$, and below the noise level of the magnetometer $(\sim 5 \mu \mathrm{A} / \mathrm{m})$ for many samples from the uppermost $20 \mathrm{~m}$ of section. However, in most of the samples, a ChRM could be isolated in the 20-70 $\mathrm{mT}$ field interval, after the elimination of a viscous component (Figure 2b). The Calcari ad Aptici samples revealed a greater intensity of magnetic remanence with respect to the Maiolica specimens $(30-270 \mu \mathrm{A} / \mathrm{m})$, and systematically yielded a well measurable remanent magnetization. In the AF cleaned samples, a ChRM could be isolated in the 25$60 \mathrm{mT}$ field interval (Figure 2c), while in the thermally cleaned samples a $\mathrm{ChRM}$ was isolated in the $380^{\circ}-580^{\circ} \mathrm{C}$ temperature interval (Figure 2d). Considering the ChRMs from the whole section, the reversal test proved positive (for class B) if the thermally cleaned Calcari ad Aptici samples are taken into account, and negative when all the ChRMs from AF cleaning are used. These results suggest that the ChRMs gathered from the Calcari ad Aptici by using the AF cleaning were biased by an unresolved secondary component. Therefore only the thermally cleaned directions from the Calcari ad Aptici were considered (Figures 2e and 3 and Table 1).

[19] The VGP latitudes define a succession of normaland reverse-polarity magnetozones (Figure 3), progressively numbered starting from the section bottom. It was assumed that the two subsections share a common, overlapping normal-polarity magnetozone $(\operatorname{arc} 2 \mathrm{n})$. Within the Calcari ad Aptici, four subzones showing a stratigraphic thickness of some tens of $\mathrm{cm}$ to about $2 \mathrm{~m}$ (Figure 3 ) were subjected to additional detailed sampling (by drilling 35 new cores) to make their existence sure, so that each of them is now defined by at least four cores from different stratigraphic positions. A total of 202 cores was drilled at Arcevia, and 324 specimens were demagnetized.

\subsection{Bosso}

[20] The well-known Bosso section is located along the road from Secchiano to Pianello $\left(43^{\circ} 31^{\prime} \mathrm{N}, 12^{\circ} 34^{\prime} \mathrm{E}\right.$, Figure 1). The road follows the valley of the Bosso river, which cuts a NW oriented anticline containing in its core Sinemurian-Pliensbachian "Corniola" pelagic limestones. The Corniola limestones and the overlying JurassicCretaceous sediments form a relatively continuous succession along the road, in the southwestern anticline limb. The Maiolica and the underlying Calcari ad Aptici (dipping toward the SSW by $19^{\circ}$ to $62^{\circ}$ ) are well exposed along the road cut. The Calcari ad Aptici are $19 \mathrm{~m}$ thick, and formed by $7 \mathrm{~m}$ of white bioclastic limestones with 5 - to 20 -cm-thick strata, passing upward to $12 \mathrm{~m}$ of pink-reddish thin-bedded cherty limestones containing aptychi and Saccocoma [Cecca et al., 1987]. The boundary with the overlying Maiolica is conventionally considered along the uppermost level of red cherts. The Calcari ad Aptici are separated from the underlying "Diaspri" (predominantly made up by layered cherts) by an exposure interruption of some meters. No fault is apparent in the whole succession encompassing the Calcari ad Aptici and the lowermost $110 \mathrm{~m}$ of Maiolica.

[21] The magnetostratigraphy of the latter and a few meters of Calcari ad Aptici was reported by Lowrie and Channell [1984], who adopted an 80-cm average sampling spacing and correlated the retrieved magnetozones to the M20n to M14 polarity chrons. More recently, Housa et al. [2004] hand-sampled the lowermost $28.5 \mathrm{~m}$ of Maiolica and the uppermost $10.5 \mathrm{~m}$ of Calcari ad Aptici (adopting an average sampling spacing of $20 \mathrm{~cm}$ ), and detailed the magnetostratigraphy across the Jurassic/Cretaceous boundary, between the chrons M20n to M17.

[22] At Bosso, we sampled oriented cores along the lowermost $84 \mathrm{~m}$ of Maiolica, and all the 19-m-thick Calcari ad Aptici succession. Of this overall 103-m-thick sequence, only the lowermost $8.5 \mathrm{~m}$ of Calcari ad Aptici had never been paleomagnetically investigated before. Our average 


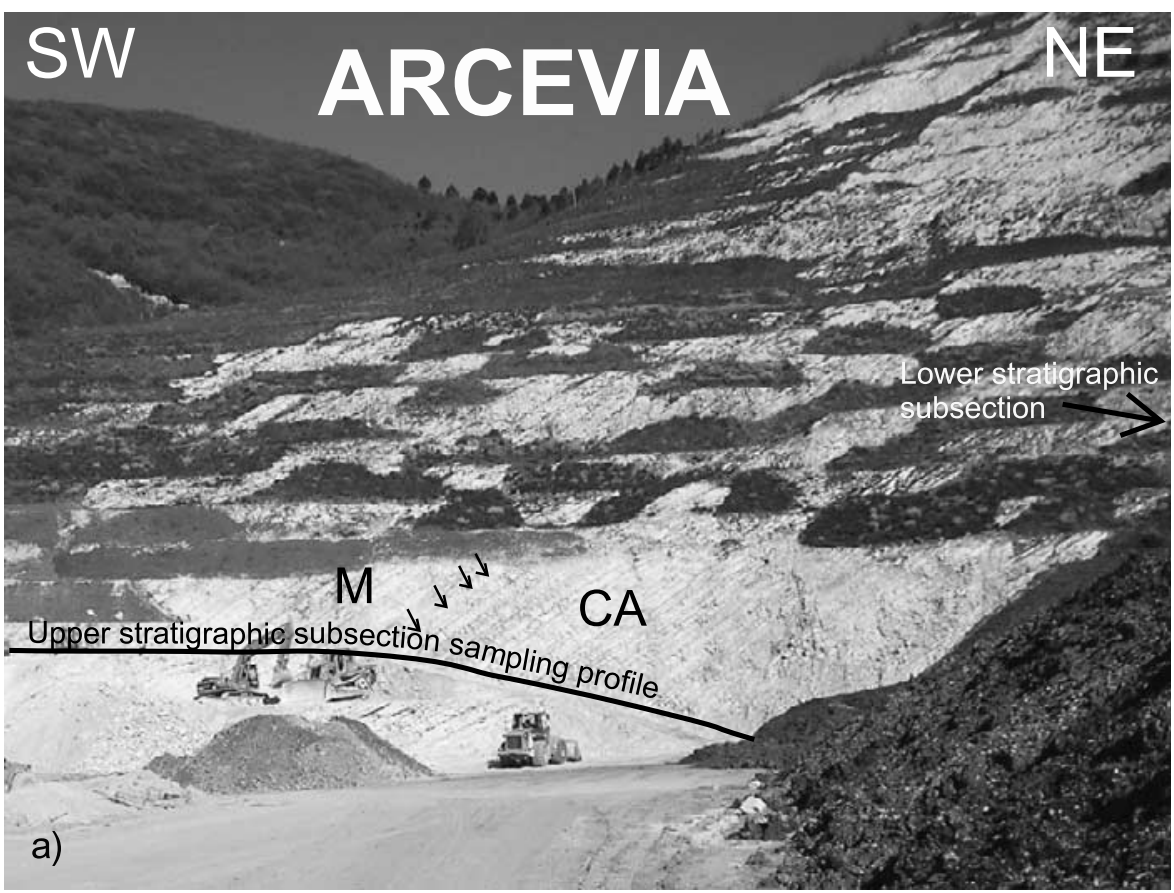

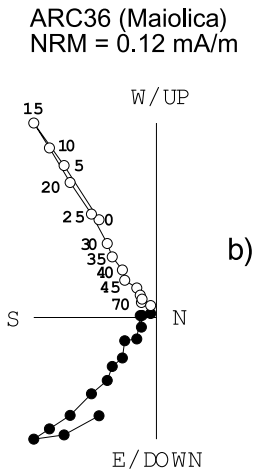

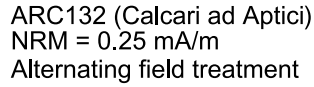

Alternating field treatment

)

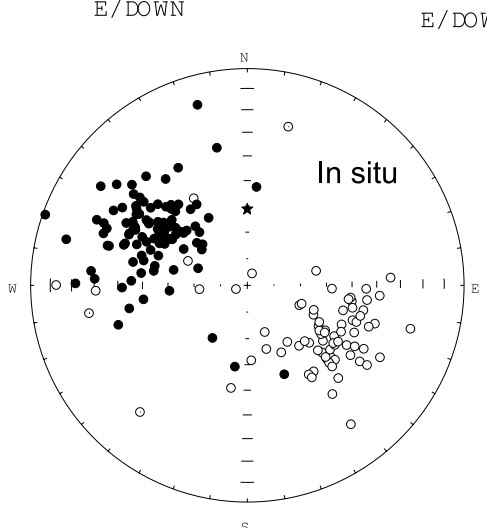

e)
ARC132 (Calcari ad Aptici)

$\mathrm{NRM}=0.26 \mathrm{~mA} / \mathrm{m}$

Thermal treatment

c)

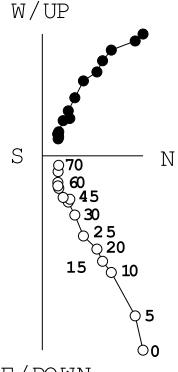

d)

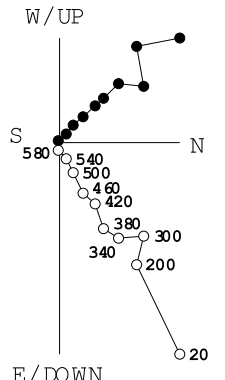

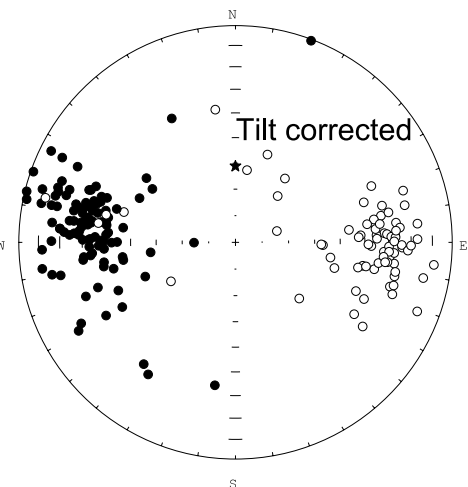

Figure 2. Paleomagnetic results from Arcevia. (a) Photo of the sampled upper stratigraphic subsection (now buried and inaccessible to sampling). The arrows indicate the stratigraphic boundary between the white Maiolica (M) and the greenish Calcari ad Aptici (CA) limestones. (b-d) Vector diagrams of demagnetization data from Maiolica (Figure 2b) and Calcari ad Aptici (Figures 2c-2d) limestones in situ coordinates. Open and solid symbols represent projection onto the vertical and horizontal planes, respectively. Data were obtained by alternating field (Figures $2 \mathrm{~b}$ and 2c) and thermal (Figure 2d) demagnetization (see text for details). Demagnetization step values are expressed in $\mathrm{mT}$ (Figures $2 \mathrm{~b}$ and $2 \mathrm{c}$ ) and ${ }^{\circ} \mathrm{C}$ (Figure 2d). (e) Equal-area projections of the ChRMs from the individual samples. Solid and open circles represent projection onto the lower and upper hemisphere, respectively. For the Calcari ad Aptici, only the ChRMs gathered by thermal cleaning are shown. The star represents the normal polarity geocentric axial dipole (GAD) field direction for the study area. 
ARCEVIA
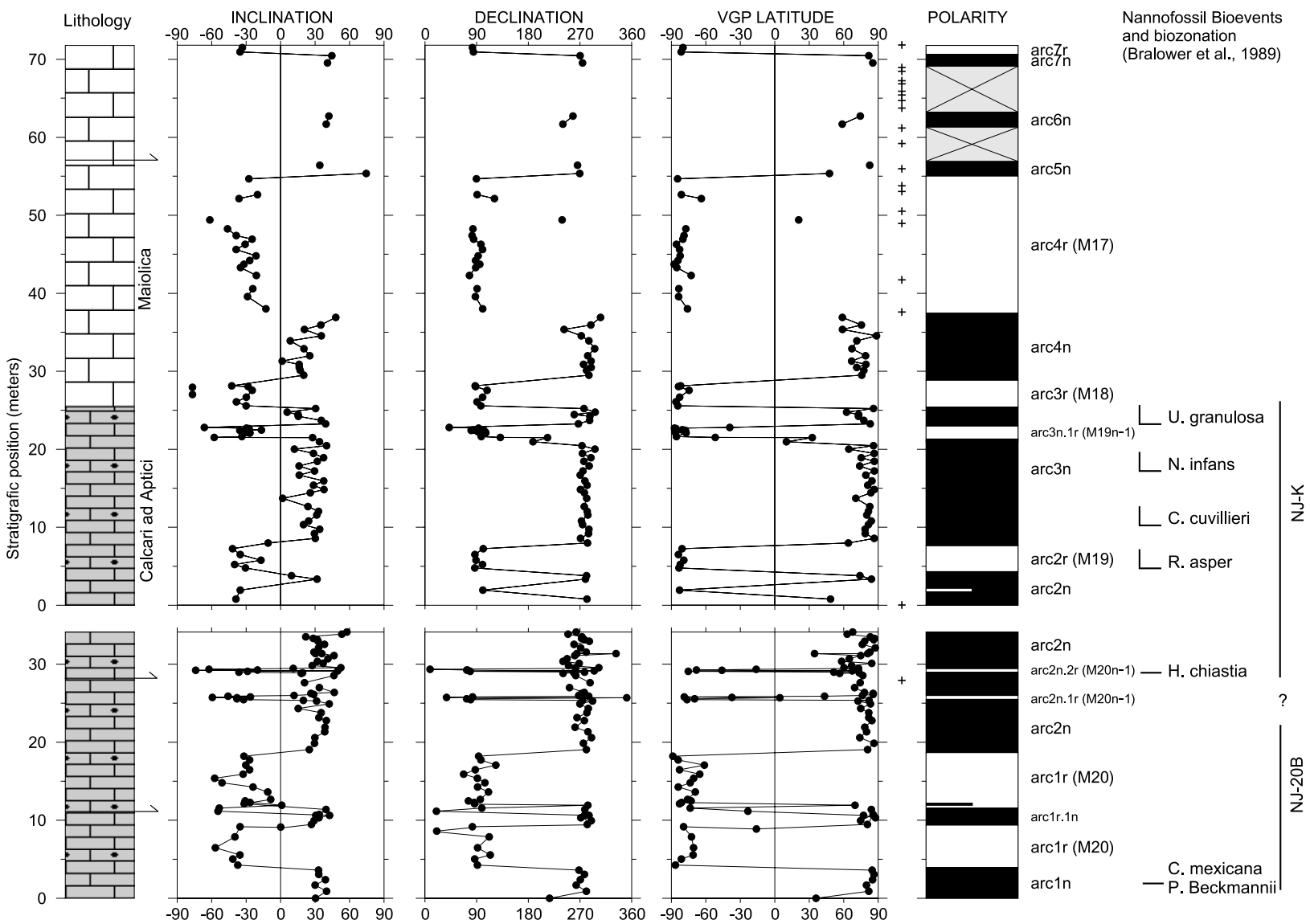

Figure 3. Arcevia section. Stratigraphic variations of inclination, declination, computed VGP latitude, magnetic polarity zones, and positions of nannofossil events. The displacement of the three indicated faults is not constrained, and the section is not restored by their throw. Conversely, the 1-m offset of a fault (not indicated) displacing the Maiolica-Calcari ad Aptici boundary is restored. Single-sample polarity zones are shown by half bars. Magnetic polarity zones and subzones are progressively numbered from the section bottom (the correlative polarity chrons are in parentheses after the polarity zone labels). Uncertain polarity intervals are grey and cross hatched. The crosses indicate failed samples.

sampling spacing was $50 \mathrm{~cm}$ in the Maiolica and $30 \mathrm{~cm}$ in the lowermost meters of Maiolica and in the whole Calcari ad Aptici Formation.

[23] In the Maiolica, the magnetic remanence was found to be moderately weak $(20-400 \mu \mathrm{A} / \mathrm{m})$, and generally well measurable. A ChRM was observed in the 20-70 mT AF field interval (Figure $4 \mathrm{a}$ ), and in the $340^{\circ}-580^{\circ} \mathrm{C}$ temperature interval for some twin specimens from some cores which were also thermally demagnetized (Figure 4b). In the Calcari ad Aptici, the natural remanent magnetization (NRM) values were significantly greater $(200-22,000 \mu \mathrm{A} / \mathrm{m})$, and a ChRM could be isolated in the $350^{\circ}-580^{\circ} \mathrm{C}$ temperature interval (Figure 4c). The ChRMs from all the samples (Figure 4d) yield a negative reversal test, pointing to a bias of a partially uncleaned overprint component.

[24] The VGP latitude data from Bosso define a succession of several magnetozones, that we have numbered from the section bottom (Figure 5). Some Maiolica strata documenting anomalous field behavior (individual VGPs departing by more than $45^{\circ}$ from the mean normal- or reverse-polarity paleomagnetic pole) within the zones bos $7 \mathrm{r}$, bos $8 \mathrm{n}$, and bos9n were resampled in greater detail. A total

Table 1. Mean Paleomagnetic Directions for the Four Studied Sections ${ }^{\mathrm{a}}$

\begin{tabular}{|c|c|c|c|c|c|c|c|c|c|}
\hline \multirow[b]{2}{*}{ Location } & \multirow[b]{2}{*}{$\mathrm{n} / \mathrm{N}$} & \multicolumn{2}{|c|}{ In Situ } & \multicolumn{4}{|c|}{ Tilt-Corrected } & \multicolumn{2}{|c|}{ Pole Position } \\
\hline & & $\mathrm{D}$, deg & I, deg & $\mathrm{D}$, deg & I, deg & $\mathrm{k}$ & $\alpha_{95}, \operatorname{deg}$ & Latitude, ${ }^{\circ} \mathrm{N} /$ Longitude, ${ }^{\circ} \mathrm{E}$ & $\mathrm{dp} / \mathrm{dm}, \mathrm{deg}$ \\
\hline Arcevia & $181 / 202$ & 300.5 & 51.7 & 272.9 & 34.7 & 10.0 & 3.5 & $15.1 / 295.1$ & $2.3 / 4.0$ \\
\hline Bosso & $214 / 234$ & 314.9 & 36.2 & 288.6 & 38.4 & 9.7 & 3.3 & $27.9 / 286.7$ & $2.3 / 3.9$ \\
\hline Contessa & $180 / 233$ & 274.3 & 36.5 & 287.2 & 44.8 & 5.8 & 4.8 & $29.9 / 291.9$ & $3.8 / 6.1$ \\
\hline Gorgo & $136 / 192$ & 257.5 & 40.6 & 265.9 & 39.6 & 7.2 & 4.8 & $12.5 / 301.9$ & $3.5 / 5.8$ \\
\hline
\end{tabular}

${ }^{\mathrm{a}}$ Abbreviations are $\mathrm{n} / \mathrm{N}$, number of cores yielding reliable results/total number of cores drilled in the section; D, declination; I, inclination. Section coordinates (Latitude, ${ }^{\circ} \mathrm{N}$; Longitude, ${ }^{\circ} \mathrm{E}$ ) are Arcevia $43^{\circ} 30^{\prime}, 12^{\circ} 56^{\prime}$; Bosso $43^{\circ} 31^{\prime}, 12^{\circ} 34^{\prime}$; Contessa $43^{\circ} 22^{\prime}$, $12^{\circ} 33^{\prime}$; Gorgo a Cerbara $43^{\circ} 35^{\prime}$, $12^{\circ} 33^{\prime}$. 


\section{BOSso}
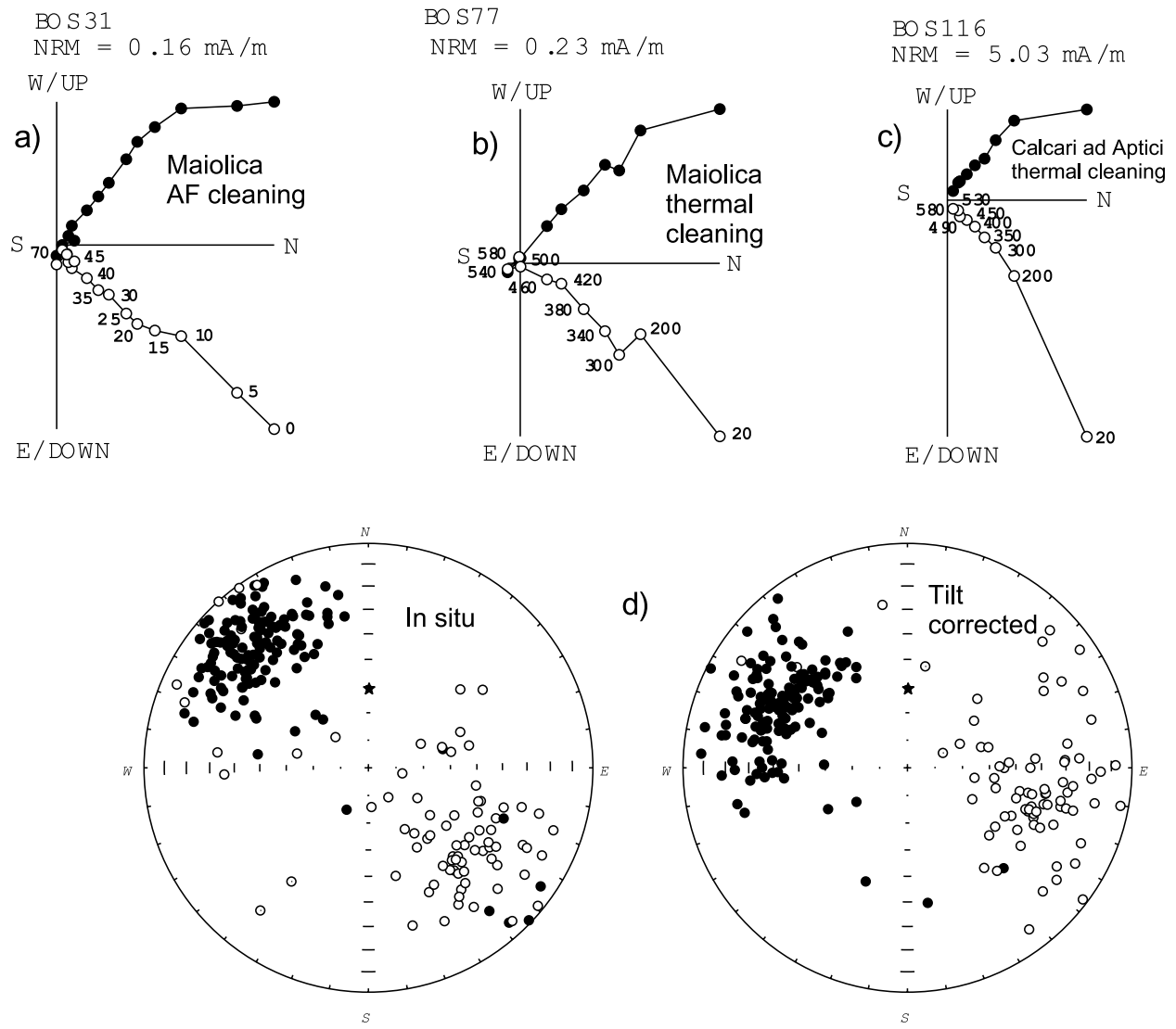

Figure 4. Paleomagnetic results from Bosso. $(\mathrm{a}-\mathrm{c})$ Vector diagrams of demagnetization data from Maiolica (Figures 4a and 4b) and Calcari ad Aptici (Figure 4c) limestones, in situ coordinates. Open and solid symbols represent projection onto the vertical and horizontal planes, respectively. Data were obtained by alternating field (Figure $4 a$ ) and thermal (Figures $4 b$ and $4 c$ ) demagnetization (see text for details). Demagnetization step values are expressed in mT (Figure 4a) and ${ }^{\circ} \mathrm{C}$ (Figures $4 \mathrm{~b}$ and $4 \mathrm{c}$ ). (d) Equal-area projections of the ChRMs from the individual samples. Solid and open circles represent projection onto the lower and upper hemisphere, respectively. The star represents the normal polarity geocentric axial dipole (GAD) field direction for the study area.

number of 234 cores were drilled at Bosso, and 255 specimens were demagnetized.

\subsection{Contessa}

[25] The Contessa valley, NW of Gubbio, hosts a spectacular part of the Umbria-Marche pelagic succession, comprised between the Maiolica limestones and the Oligocene Scaglia marls. All strata are perfectly exposed along several quarry and road cuts. This section is celebrated by paleomagnetists, as magnetostratigraphic studies carried out in the Tertiary Scaglia limestones [Lowrie et al., 1982] provided both an independent validation of the succession of polarity chrons inferred from oceanic magnetic anomaly profiles, and an age calibration of several biostratigraphic events. More recently, also the Albian part of the "Fucoidi" marls (stratigraphically interposed between the Maiolica and Scaglia limestones) was investigated [Tarduno et al., 1992]. Here, several intervals of reverse magnetization in the lower part of the long normal Cretaceous superchron were reported.

[26] We document now the magnetic stratigraphy of the Maiolica Formation, which had never been studied to date, thus completing the magnetostratigraphic analysis of the whole pelagic succession laid bare in the Contessa valley. The studied section is located in the "Fratelli Vispi" quarry $\left(43^{\circ} 22^{\prime} \mathrm{N}, 12^{\circ} 33^{\prime} \mathrm{E}\right.$, Figure $\left.6 \mathrm{a}\right)$, where a $\sim 150 \mathrm{~m}$ high subvertical wall was excavated within the Maiolica limestones. Strata dip gently toward the NE, and are separated from the overlying Fucoidi marls by a decametric-scale chaotic level formed by slumps of Maiolica beds (Figure 6a). The $\sim 110$-m-thick exposed section of Maiolica is cut by several (predominantly strike slip) faults, generally producing offsets of some meters, which were all resolved and restored in the stratigraphic column.

[27] We sampled the whole exposed Maiolica sequence with an average sampling spacing of $50 \mathrm{~cm}$, starting from a few meters below the chaotic level. At $8.4 \mathrm{~m}$ of stratigraphic depth within our sampling profile, the Faraoni guide level [Cecca et al., 1994b] is well exposed, and can be followed for several tens of meters along the quarry wall (Figure 6a). It is formed by a $\sim 20$-cm-thick ammonite-rich limestone bed ("guide bed") bounded by two thin black shale intervals with high organic matter content. We sampled 

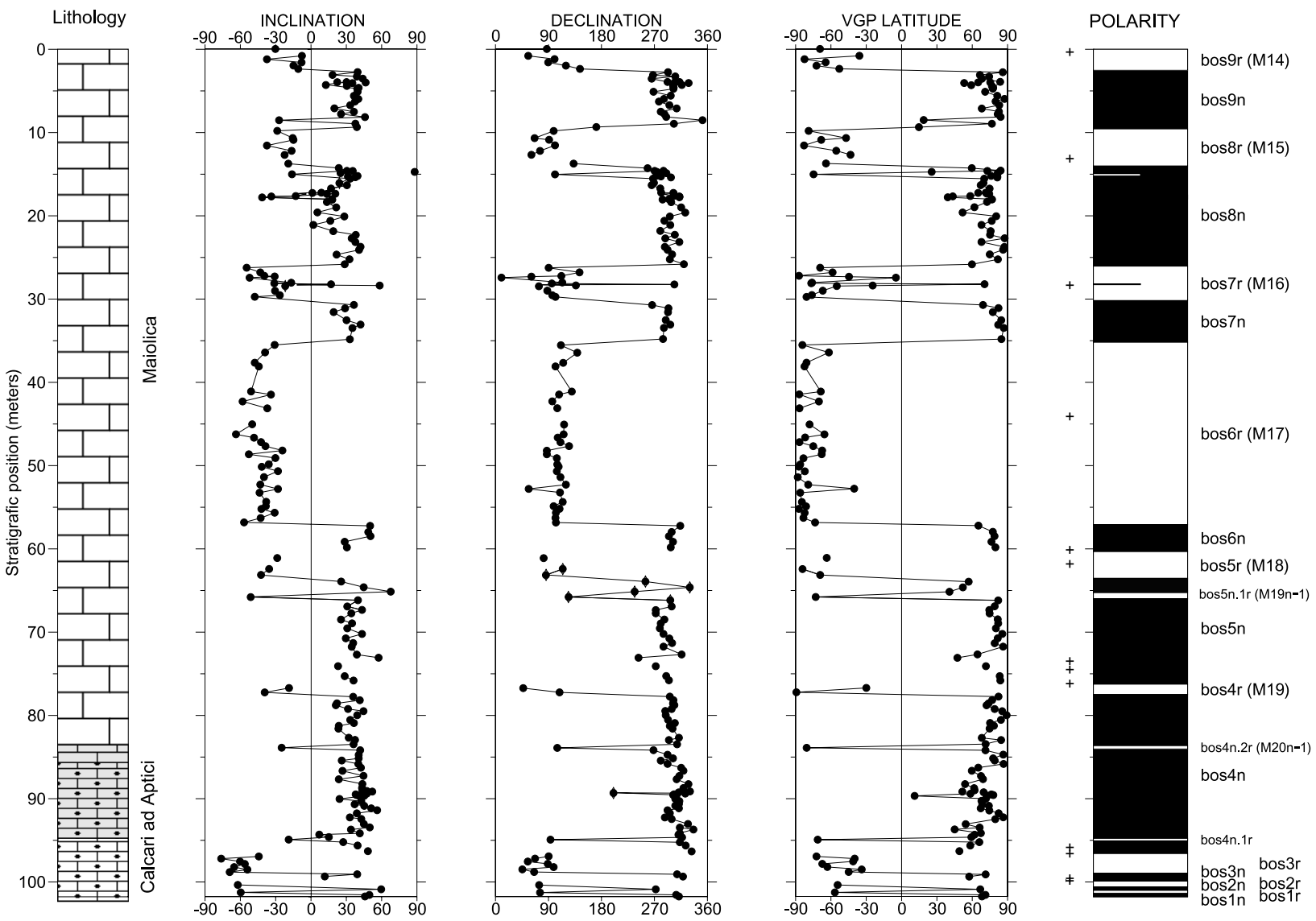

Figure 5. Bosso section. Stratigraphic variations of inclination, declination, computed VGP latitude and magnetic polarity zones. Single-sample polarity zones within zones bos $8 n$ and bos $7 r$ (resampled in detail) are shown by half bars. Magnetic polarity zones and subzones are progressively numbered from the section bottom (the correlative polarity chrons are in parentheses after the polarity zone labels). The crosses indicate failed samples.

both the Faraoni guide bed, and the limestones just above and below the black shales.

[28] The NRM was found to be very weak, and 53 samples (i.e., $23 \%$, mostly from the central part of the succession), were too weak to be measured (i.e., $<5 \mu \mathrm{A} / \mathrm{m}$ ). In the remaining samples, a ChRM was isolated in the $20-$ $70 \mathrm{mT}$ field interval (Figure 6b). Twin specimens from some cores were also thermally cleaned, and yielded a ChRM in the $340^{\circ}-560^{\circ} \mathrm{C}$ temperature interval (Figure $6 \mathrm{c}$ ). The normal- and reverse-polarity ChRMs are visibly not antipodales (Figure 6d), as confirmed by the negative result of the reversal test. The reverse-polarity ChRMs appear more scattered, and are often close (both in situ and tilt-corrected coordinates) to the reverse-polarity geocentric axial dipole field direction expected for the Contessa section $\left(\mathrm{D}=180^{\circ}, \mathrm{I}=-62^{\circ}\right)$. This evidence may suggest a partial or complete overprint of some samples during a recent reverse-polarity chron, possibly during the (unconstrained in time) activity of the strike-slip faults crosscutting the section.

[29] The VGP latitudes evaluated from the individual ChRMs define a clear succession of magnetozones only for the uppermost 40 and the lowermost $25 \mathrm{~m}$ of the section, while within the central $45 \mathrm{~m}$ of the section the few samples with measurable magnetization intensity do not allow us to safely constrain the magnetostratigraphy (Figure 7). The samples from the Faraoni guide bed, and from the limestones $50 \mathrm{~cm}$ above and below the black shales were found

Figure 6. Paleomagnetic results from Maiolica at Contessa. (a) Photo of the section, showing the sampled Maiolica limestones (Ma) passing upward to the Fucoidi marls $(\mathrm{Fu})$ and to the Scaglia limestones (Sc). S1 is a chaotic level formed by slumped Maiolica beds, Fa is the uppermost Hauterivian "Faraoni" ammonite guide level (indicated by small arrows). $(b-c)$ Vector diagrams of alternating field (Figure 6b) and thermal (Figure 6c) demagnetization data, in situ coordinates. Open and solid symbols represent projection onto the vertical and horizontal planes, respectively. Demagnetization step values are expressed in $\mathrm{mT}$ (Figure $6 \mathrm{~b}$ ) and ${ }^{\circ} \mathrm{C}$ (Figure 6c). (d) Equal-area projections of the ChRMs from the individual samples. Solid and open circles represent projection onto the lower and upper hemisphere, respectively. The star represents the normal polarity geocentric axial dipole (GAD) field direction for the study area. 


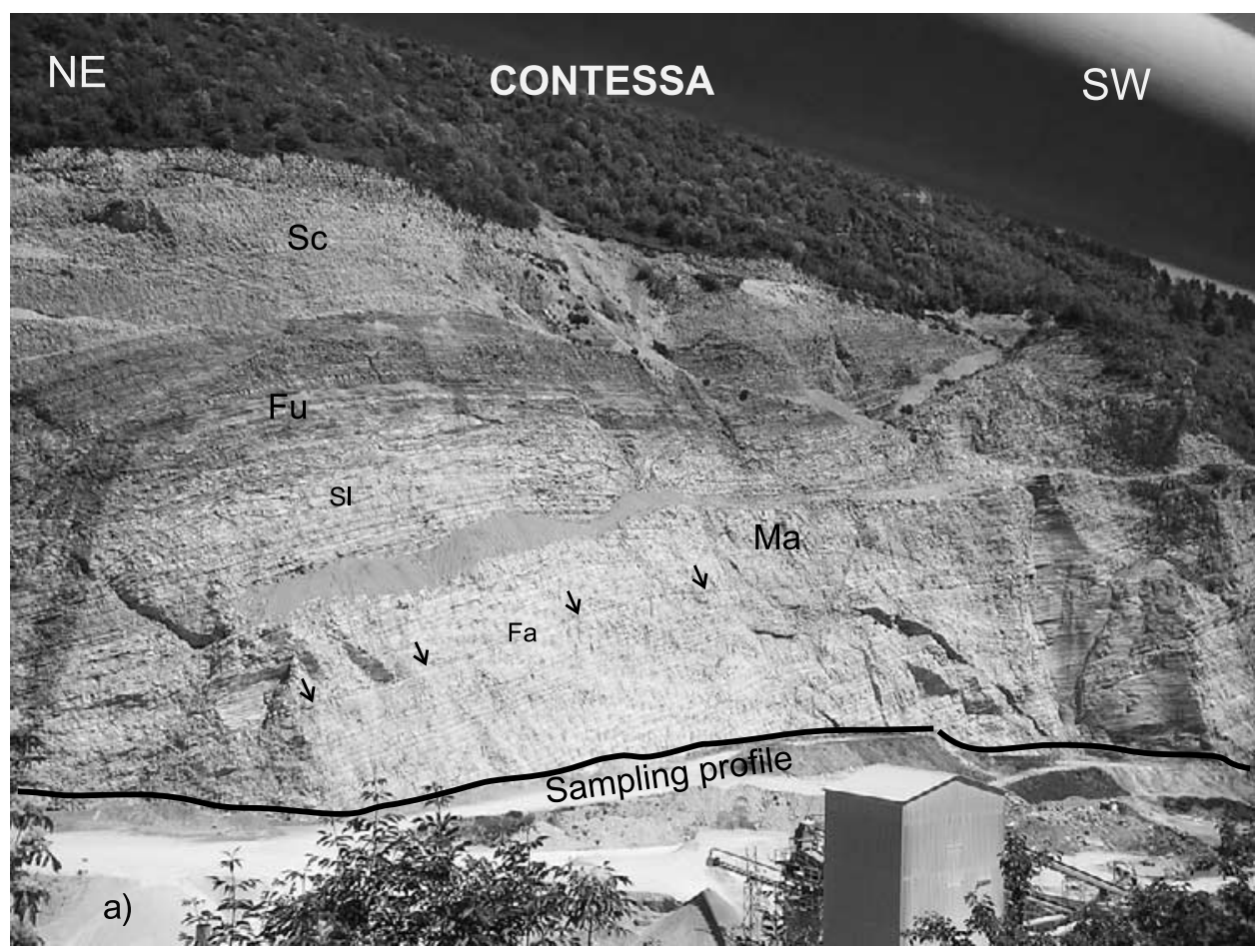

$\mathrm{CON} 208$

$\mathrm{NRM}=0.17 \mathrm{~mA} / \mathrm{m}$

b)

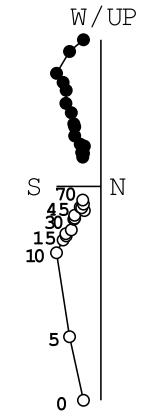

E/DOWN

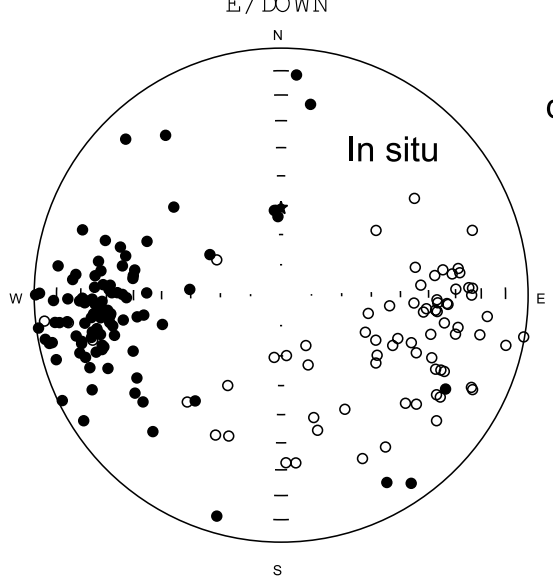

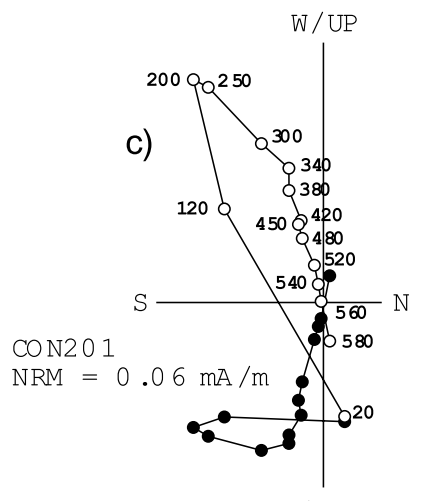

E/DOWN

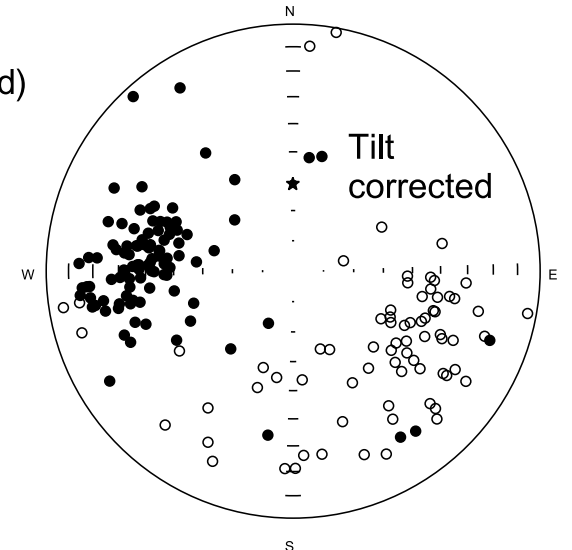

Figure 6 
CONTESSA
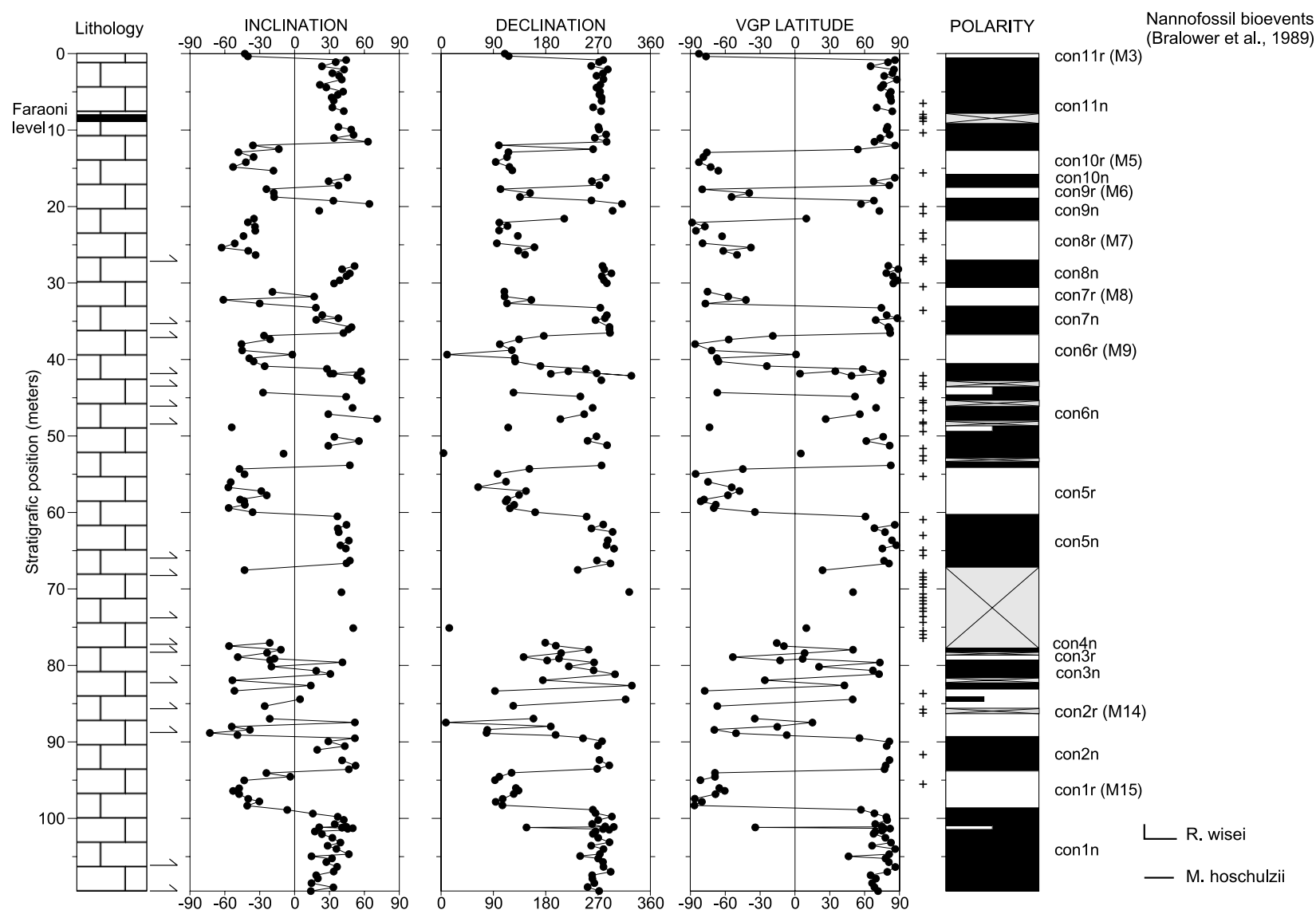

Figure 7. Contessa section. Stratigraphic variations of inclination, declination, computed VGP latitude, magnetic polarity zones, and positions of nannofossil events (only for the lowermost $13 \mathrm{~m}$ of section). The displacements along the faults could be measured and are always restored in the stratigraphic column. Single-sample polarity zones are shown by half bars. Magnetic polarity zones and subzones are progressively numbered from the section bottom (the correlative polarity chrons are in parentheses after the polarity zone labels). Uncertain polarity intervals are grey and cross hatched. The crosses indicate failed samples.

to be not magnetized. The layers around a single sample showing a VGP departing by $124^{\circ}$ from the mean paleomagnetic pole of the section within the zone conln (sample CON209 at $101.2 \mathrm{~m}$, Figure 7) were resampled in detail. A total of 233 cores were drilled, and 240 specimens were demagnetized at Contessa.

\subsection{Gorgo a Cerbara}

[30] The Gorgo a Cerbara Maiolica limestones and Fucoidi marls succession $\left(43^{\circ} 35^{\prime} \mathrm{N}, 12^{\circ} 33^{\prime} \mathrm{E}\right.$, Figure $8 \mathrm{a}$ ) has been extensively investigated in the last 25 years and yielded excellent magnetostratigraphy and biostratigraphic results. It is located along the Candigliano river, between
Piobbico and Acqualagna, in the northeastern limb of an anticline showing in its core the Calcare Massiccio shelf limestones. The magnetostratigraphy of the uppermost $60 \mathrm{~m}$ of Maiolica was reported by Lowrie et al. [1980], who also paleomagnetically studied the overlying Fucoid marls. Normal sampling spacing in the Maiolica was $\sim 1 \mathrm{~m}$, reduced to $\sim 20 \mathrm{~cm}$ for the uppermost $10 \mathrm{~m}$. Lowrie and Alvarez [1984] sampled downsection an additional $120 \mathrm{~m}$ of Maiolica, adopting a sampling interval of $0.75-1 \mathrm{~m}$. Channell et al. [2000] further analyzed in great detail the uppermost $6 \mathrm{~m}$ of Maiolica.

[31] The magnetostratigraphic studies demonstrated that the Maiolica limestones sampled at Gorgo a Cerbara were

Figure 8. Paleomagnetic results from Maiolica at Gorgo a Cerbara. (a) Photo of the section, showing the Maiolica limestones $(\mathrm{Ma})$ and the overlying Fucoidi marls $(\mathrm{Fu}) .(\mathrm{b}-\mathrm{c})$ Vector diagrams of alternating field (Figure 8b) and thermal (Figure 8c) demagnetization data, in situ coordinates. Open and solid symbols represent projection onto the vertical and horizontal planes, respectively. Demagnetization step values are expressed in $\mathrm{mT}$ (Figure $8 \mathrm{~b}$ ) and ${ }^{\circ} \mathrm{C}$ (Figure $8 \mathrm{c}$ ). (d) Equal-area projections of the ChRMs from the individual samples. Solid and open circles represent projection onto the lower and upper hemisphere, respectively. The star represents the normal polarity geocentric axial dipole (GAD) field direction for the study area. 


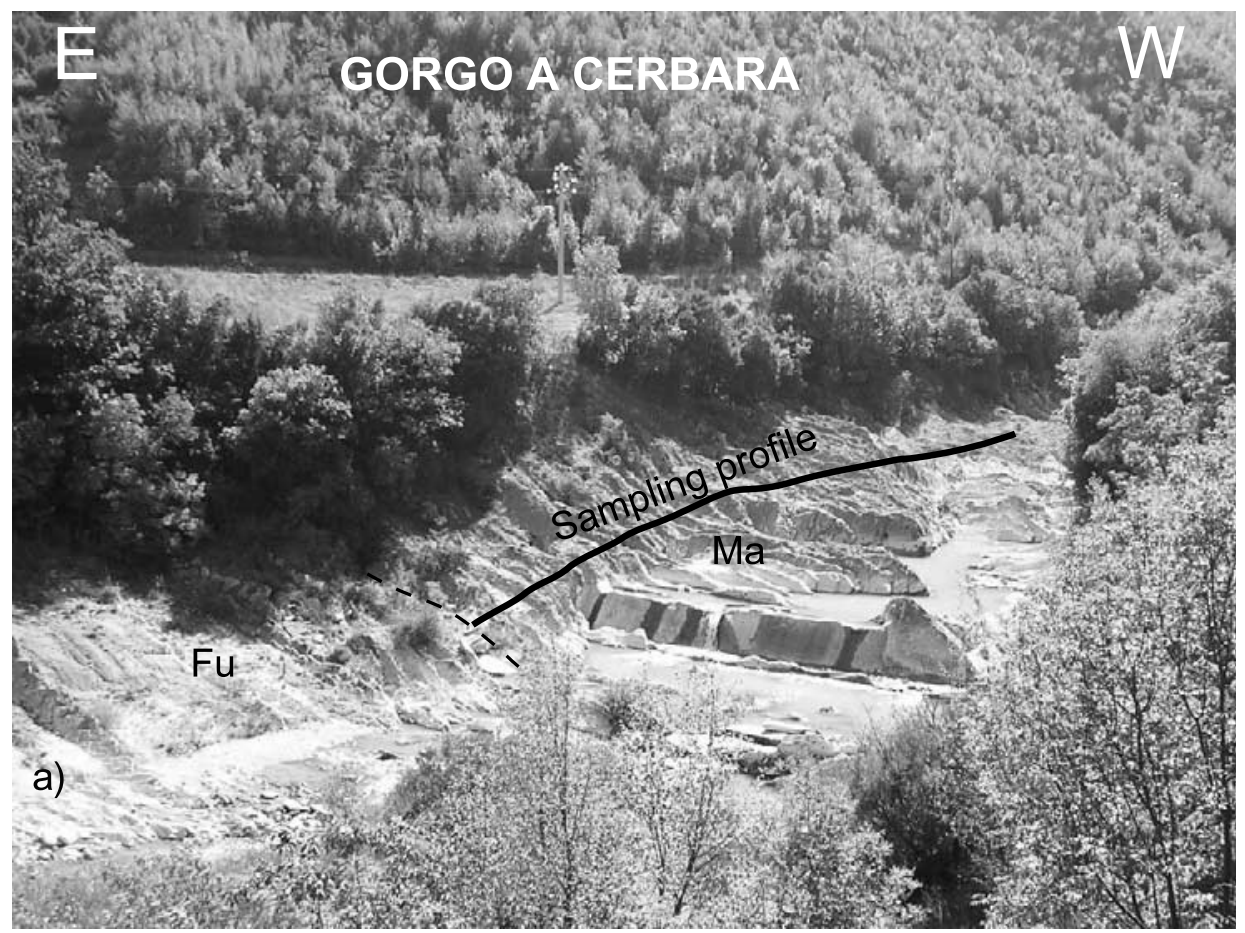

GO R13

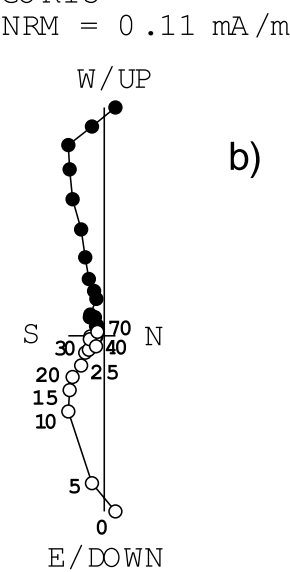

GO RO 4

$\mathrm{NRM}=0.06 \mathrm{~mA} / \mathrm{m} \quad \mathrm{W} / \mathrm{UP}$

c)

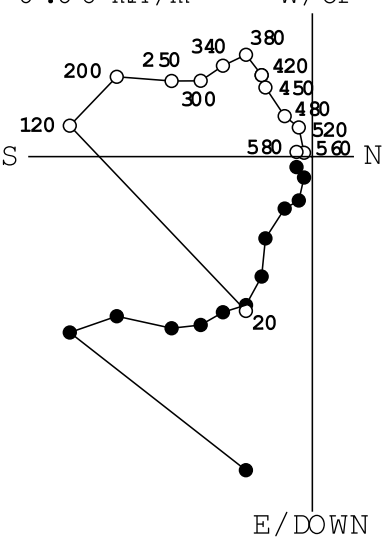

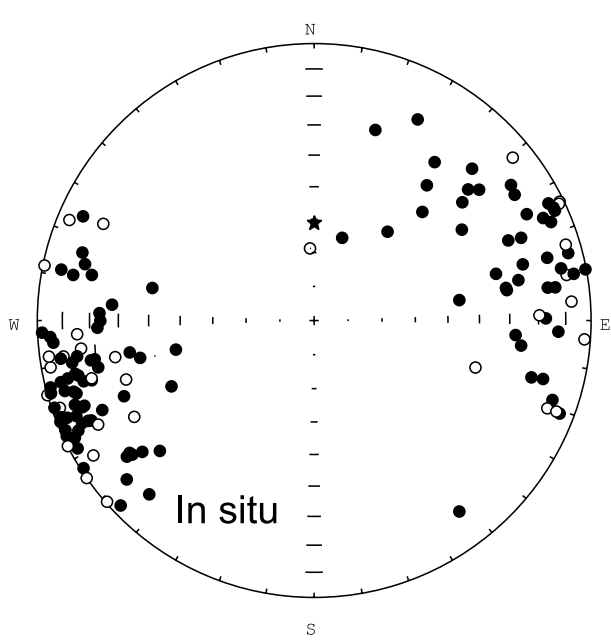

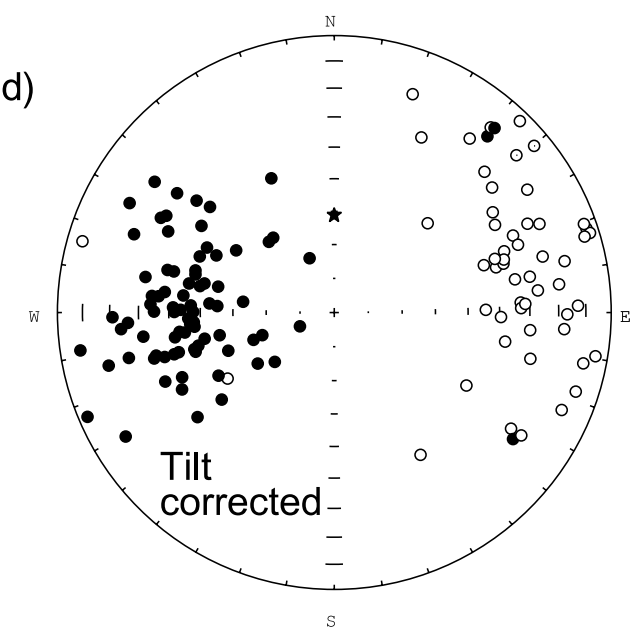

Figure 8 


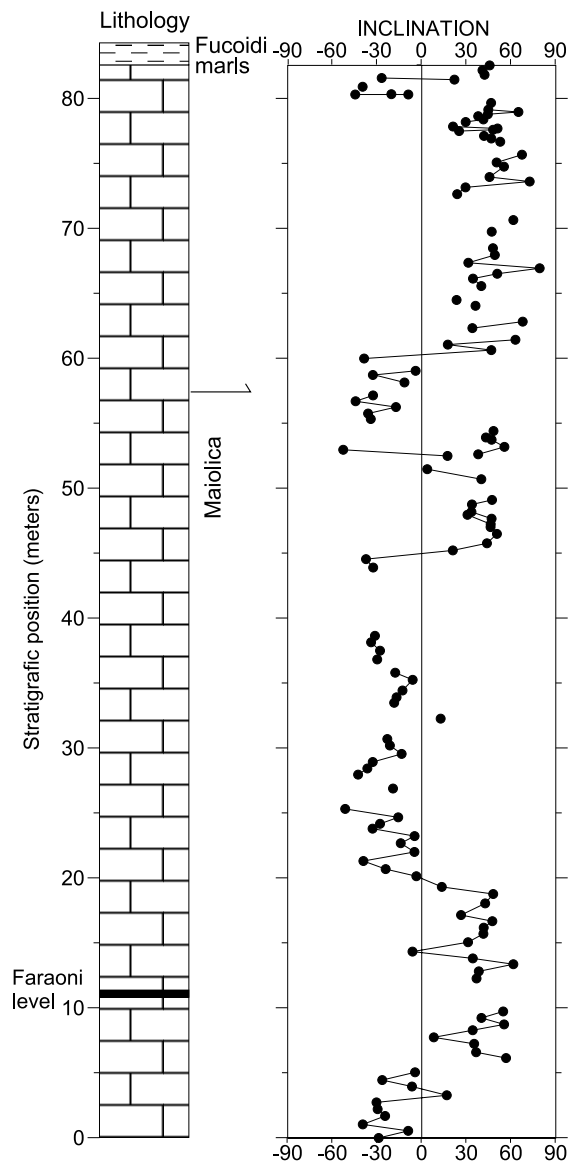

\section{GORGO A CERBARA}
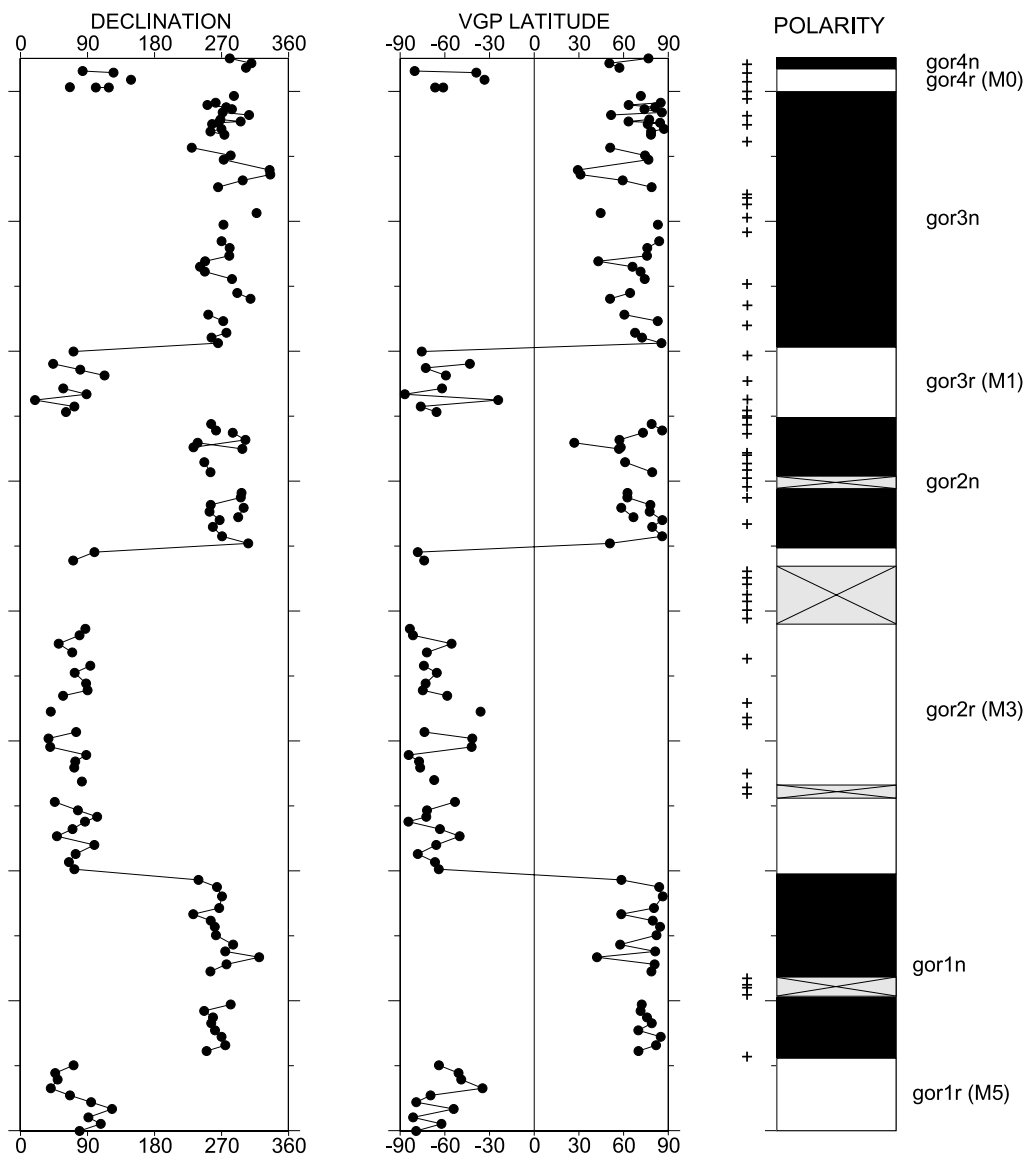

Figure 9. Gorgo a Cerbara section. Stratigraphic variations of inclination, declination, computed VGP latitude and magnetic polarity zones. In the stratigraphic column, the measured displacement of a normal fault at $57 \mathrm{~m}$ is restored. Magnetic polarity zones and subzones are progressively numbered from the section bottom (the correlative polarity chrons are in parentheses after the polarity zone labels). Uncertain polarity intervals are grey and cross hatched. The crosses indicate failed samples.

deposited from the M11n chron to the bottom of the long normal Cretaceous superchron. The M0 chron is constrained within the uppermost $3 \mathrm{~m}$ of Maiolica, according to Channell et al. [2000]. Channell et al. [1995a] correlated new ammonite finds (and those published by Cecca et al. [1994a]) at Gorgo a Cerbara with the magnetostratigraphy from Lowrie and Alvarez [1984], correlating stage boundaries to polarity chrons. They also showed that the Faraoni guide level (exposed in the Maiolica at about $70 \mathrm{~m}$ below the boundary with the Fucoid marls) is located within the M5n chron.

[32] At Gorgo a Cerbara, we resampled the uppermost $82 \mathrm{~m}$ of Maiolica, adopting a normal sampling spacing of 50 and $20 \mathrm{~cm}$ for the uppermost $8 \mathrm{~m}$. At $36 \mathrm{~m}$ below the contact with the Fucoidi marls, the Maiolica limestones are cut by a normal fault, whose $\sim 10 \mathrm{~m}$ offset could be restored thanks to a distinctive 1-m-thick slump bed (as also indicated by Lowrie et al. [1980]).

[33] The NRM was found to be very weak, and in the case of 56 samples (i.e., 29\%) below the noise level of the magnetometer. The measurable samples yielded a ChRM in the 20-50 mT field interval (Figure 8b), while twin specimens from some cores thermally demagnetized gave coherent $\mathrm{ChRMs}$ in the $380^{\circ}-560^{\circ} \mathrm{C}$ temperature interval
(Figure 8c). The ChRMs from the whole section are not perfectly antipodal (Figure 8d) and the reversal test is negative, suggesting again that the ChRMs are partly biased by an overprint component.

[34] The VGP latitudes clearly define a succession of eight magnetozones (Figure 9), though in few sectors could the polarity not be satisfactorily defined due to the high number of failed (too weak) samples. As at Contessa, the samples from the Faraoni guide bed, and from the limestones $50 \mathrm{~cm}$ above and below the black shales were found to be not magnetized. After the first sampling campaign, the magnetozone gor $4 \mathrm{r}$ was poorly defined, so that we collected ten additional cores within these reversely magnetized layers. A total of 192 cores was drilled and 202 samples were demagnetized at Gorgo a Cerbara.

\section{Biostratigraphic Data and Correlation With the GPTS}

\subsection{Arcevia}

[35] The interval studied for nannofossils is comprised between the samples ARC66 (meter 23.3 of the upper subsection, $\sim 3 \mathrm{~m}$ below the Maiolica-Calcari ad Aptici boundary) and ARC144 (bottom of the lower subsection, 


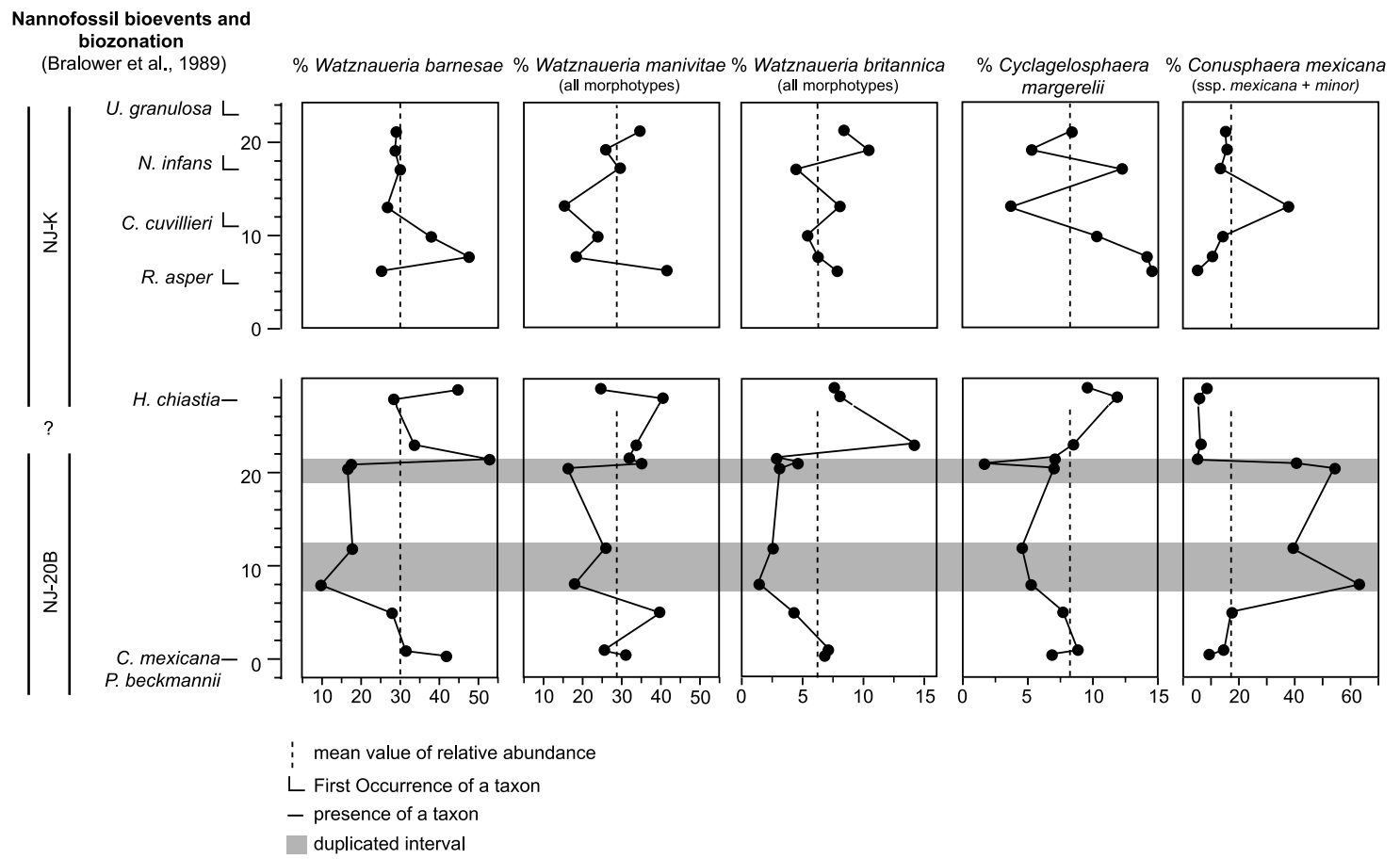

Figure 10. Percentages of the most common nannofossil species along the Arcevia subsections. Stratigraphic positions and meters are as in Figure 3. Conusphaera mexicana displays abundance peaks $(\sim 50-60 \%)$ only in two intervals (shaded) separated by a fault. These two intervals also display a very similar assemblage composition, suggesting a tectonic duplication of this part of the Arcevia lower subsection.

Figures 3, 10, and 11). All the samples analyzed yielded nannofossils in moderate to relatively high quantities. Overall preservation is moderate, overgrowth dominating over etching. Diagenetic overprint is thought to be limited and the recorded nannofossil assemblage can be regarded as quite close to that of the pristine assemblage. A total number of 39 taxa was recorded in the samples analyzed, comprising different-sized morphotypes of Watznaueria britannica [Pittet and Mattioli, 2002; Olivier et al., 2004; Giraud et al., 2003] and of Watznaueria manivitae [Pittet and Mattioli, 2002; Bornemann et al., 2003; Olivier et al., 2004], that likely correspond to a continuum in ecophenotypic morphological variability. Species richness is relatively low, varying between 11 and 26 (mean 19) species/sample. It is well known that the Upper Jurassic nannofossil assemblages are very often low-diversified and oligospecific, and are dominated in turn by various species of the genus Watznaueria (i.e., $W$. britannica and W. barnesae [see, e.g., Lees et al., 2004]). In the studied samples, the different species of the genus Watznaueria account for $\sim 80 \%$ on average of the total assemblage. The dominating taxa are $W$. barnesae (mean relative abundance $30 \%$; Figure 10 ) and $W$. manivitae (on average $28.57 \%$ ). Watznaueria britannica, which is dominant in the Kimmeridge Clay Formation of southern England [Lees et al., 2004], only accounts in Arcevia for $6.33 \%$ of the assemblage. Conusphaera mexicana (both ssp. mexicana and minor) although showing some peaks of high relative abundance (up to $\sim 60 \%$ ), displays a mean abundance value of $17.45 \%$. The general composition of the assemblage, that is undoubtedly controlled by the palaeoenvironment, dis- plays some similarities with events reported by different authors that may have a biostratigraphical significance. Namely, Bown and Cooper [1998] reported a decline in W. britannica occurring in the Mid-Tithonian, after a longlasting period of dominance of this taxon. According to their Figure 4.2, this decline may correspond to the lower part of the M20n. The assemblages recorded at Arcevia seem to coincide or postdate the W. britannica decline. Also, Bornemann et al. [2003] reported assemblages dominated by Conusphaera, Polycostella beckmannii and large-sized Watznaueria manivitae (the "Nannofossil Calcification Event") from the Middle to Late Tithonian of the central Atlantic. As a similar assemblage composition is observed in this work, the portion of the Arcevia section analyzed for nannofossil biostratigraphy seems to correspond in age to the Mid to Late Tithonian.

[36] Some biomarkers that can be of biostratigraphic use were also recorded in the Arcevia section. From the base, Conusphaera mexicana (ssp. mexicana and minor) are found together with Polycostella beckmannii. This indicates that the base of the section is in the nannofossil zone NJ-20, NJ-20B subzone, of Bralower et al. [1989]. According to the correlations between magnetostratigraphy and biostratigraphy proposed by Bralower et al. [1989], these nannofossil zones correspond to the topmost M21n and M20. Unfortunately, only sparse specimens of Helenea chiastia are recorded in Arcevia. We are therefore unable to define the base of the following NJ-K nannofossil zone. Starting from the sample ARC 96A (4.8 $\mathrm{m}$ of the upper subsection, Figures 3, 10, and 11[Appendix A]), a succession of first occurrences (FO) is recorded, namely, the FOs of Rhago- 


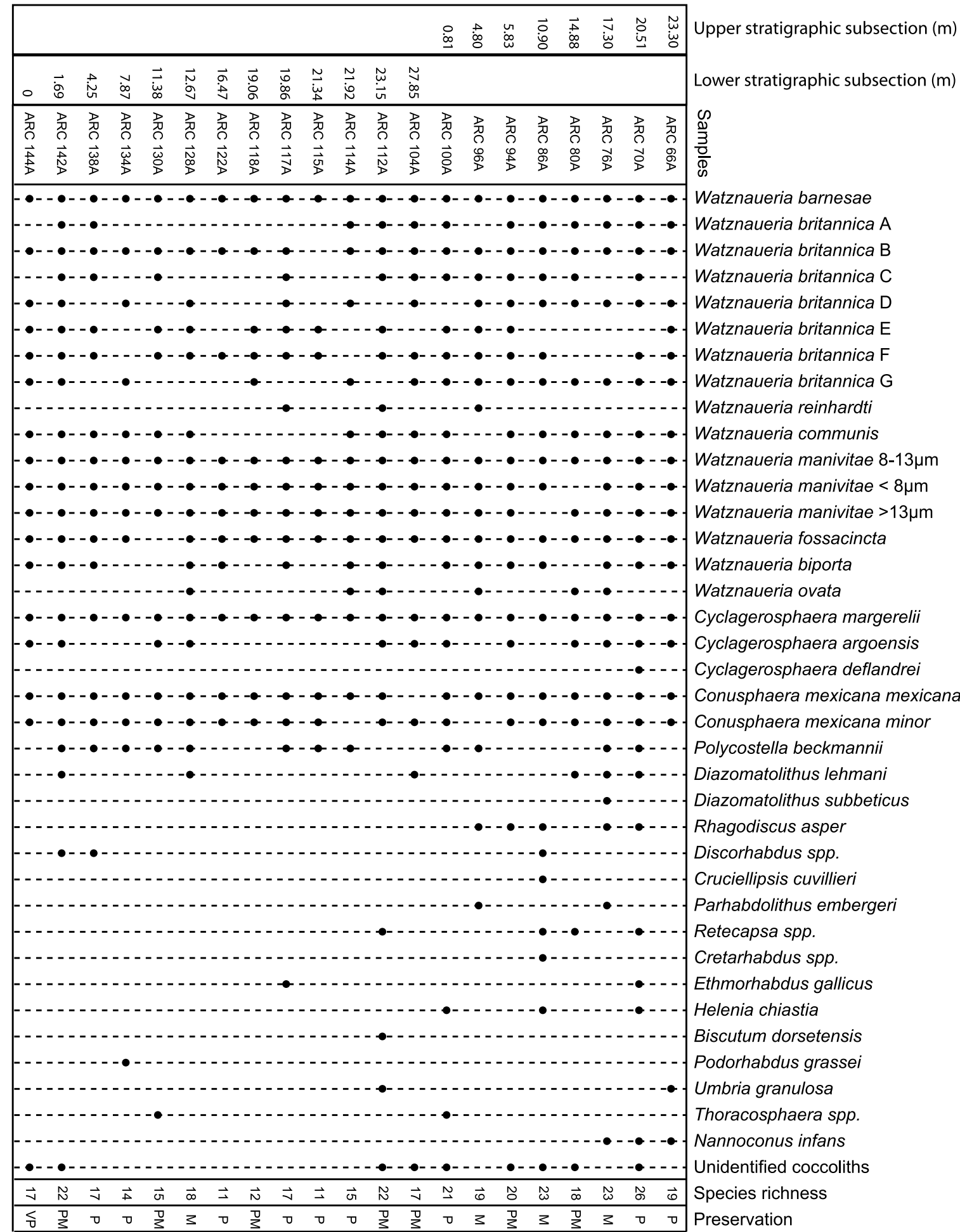

Figure 11. Distribution chart of calcareous nannofossils in the Arcaiva section. Meter levels in the lower subsection are not corrected for fault displacements. The difference morphotyps of Watznaueria britannica and the different-sized Watznaueria manivitae are also reported. Presentation is discussed in the text.

discus asper (ARC96A), Cruciellipsis cuvillieri (ARC86A, meter 10.9), Nannoconus infans (ARC76A, meter 17.3), and Umbria granulosa (ARC66A, meter 23.3). All these events, although in a partially different stratigraphical order, are reported by Bralower et al. [1989] within the M19n.
[37] Conusphaera mexicana displays abundance peaks $(\sim 50-60 \%)$ only in two intervals between the samples ARC130A-134A (7.9-11.4 $\mathrm{m}$ of the lower subsection, just below the fault) and ARC117A-118A (19.1-19.9 m). These two intervals further display a very similar assem- 
blage composition (Figure 10). These biostratigraphical data suggest a tectonic duplication of this part of the Arcevia section.

[38] Considering the biostratigraphic data, the pattern of magnetozones as observed in Figure 3 can be satisfactorily framed into the GPTS by GRAD94. The thick $(\sim 18 \mathrm{~m})$ reverse-polarity magnetozone $\operatorname{arc} 4 \mathrm{r}$ is correlated to the polarity chron M17, while the normal zone arc3n (containing a reverse subzone in its upper part) is inferred to represent the record of chron M19n (Figure 12). As a consequence, the zone arc $2 \mathrm{n}$, containing two short reverse-polarity subzones, is correlated to the M20n chron. By considering the magnetozone succession below arc $2 \mathrm{n}$, the normal zone arc1n at the section bottom would represent the M22n chron, but this correlation gives a very irregular sedimentation rate path, and biostratigraphic data indicate that the zone arc1n corresponds in fact to the M21n chron. Subsequently, we suggest that the fault observed within the subzone arc1r.1n (Figure 3) has completely duplicated the reverse zone arc1r, implying that both the zone arcln and the top of arc1r.1n correspond to the same polarity chron, M21n. This interpretation is corroborated by biostratigraphic data (Figure 10), showing an almost identical peak of abundance of Conusphaera mexicana at both the bottom of $\operatorname{arc} 2 \mathrm{n}$ and arc1r.1n, suggesting that these layers can both be correlated with the bottom of chron M20n.

[39] According to GRAD94, the M20n chron contains only one reverse-polarity subchron (M20n-1), while in our zone $\operatorname{arc} 2 \mathrm{n}$, that we have correlated to M20n, two close 34- and 44-cm-thick reverse subzones are observed (Figure 3). A fault was observed between these subzones, so that again we infer that the two subzones represent the tectonic duplication a single subzone corresponding to the M20n-1 subchron (Figure 12a/11a).

[40] By restoring both fault duplications, and assuming that the zones arc $2 n$ from the two subsections are in complete overlap, we derive a sedimentation rate which is very high in the upper part of the Calcari ad Aptici (16.5 m/Myr during chron M19n), but decreases to 10.8 (average from top of chron M17 to bottom of M18) and $7.3 \mathrm{~m} / \mathrm{Myr}$ (during chron M20) in the Maiolica and in the lower part of the Calcari ad Aptici, respectively (Figure 12a/11a). After correcting the tectonic duplications, the Calcari ad Aptici shows a total thickness of $43 \mathrm{~m}$ (Table 2), which is more than twice the maximum thickness reported so far for this formation ( $\sim 20 \mathrm{~m}$ at both Bosso and Sentino [Cecca et al., 1987]).

[41] We have shown that at Arcevia, the sedimentation rate decreases passing upward from the Calcari ad Aptici to Maiolica, while an opposite trend had been previously suggested for the Umbria-Marche basin [Cecca et al., 1987]. We also note that the Maiolica-Calcari ad Aptici boundary occurs at the top of the M19n chron (Figure 3), thus falling in the Lower Berriasian according to GRAD94, while at Bosso it has been constrained in the upper part of chron M20n [Housa et al., 2004], and the facies of the Calcari ad Aptici was completely different to that at Arcevia. We conclude that the Maiolica-Calcari ad Aptici boundary is diachronous, and may vary by $1.5-2 \mathrm{Myr}$ (following the timescale from GRAD94) in the different Umbria-Marche sections. However, we note that the excellent strata exposure at Arcevia (due to quarrying a few days before our sampling) allowed us to easily note the difference between white and greenish calcareous strata (that we associated to the Maiolica and Calcari ad Aptici, respectively, Figure 2a), whereas the same lithostratigraphic criterion may be more difficult to appreciate in less fresh outcrops.

[42] Ogg et al. [1991] noted that the passage from Maiolica to the underlying Rosso Ammonitico in sections from the central Atlantic, Spain, and northern Italy may vary from polarity chrons M22n to M19n, implying that this lithologic change is likely the result of shifting local patterns of fertility overprinted on the main regional trends. Here we document for the first time that the transition from Maiolica to the underlying Calcari ad Aptici varies from the top of chron M19n to the upper part of chron M20n within the same Umbria-Marche basin. Our biostratigraphic evidence from Arcevia confirms the Mid-Late Tithonian "Nannofossil Calcification Event" documented by Bornemann et al. [2003], who suggested that the Tithonian-Berriasian transition is characterized by an increase of the primary productivity but also by the presence of smaller coccoliths, resulting in a smaller production of pelagic carbonate mud.

[43] Arcevia is the third section reported so far documenting both the M19n-1 and M20n-1 subchrons, besides Brodno (western Slovakia [Housa et al., 1999]) and Bosso [Housa et al., 2004] (Figure 13), which however display both lower sedimentation rates during the interval encompassing the M19n and M20n chrons (2.5 and $11.3 \mathrm{~m} / \mathrm{Myr}$, respectively). The sedimentation rates at Arcevia (16.5 m/Myr during M19n decreasing to $7.3 \mathrm{~m} / \mathrm{Myr}$ during M20) are also greater than other Mid-Upper Tithonian land sections, such as Carcabuey, Spain [Ogg et al., 1984], Xausa, Frisoni Valle del Mis and Quero, northern Italy [Channell and Grandesso, 1987], and Foza, northern Italy [Ogg, 1981].

\subsection{Bosso}

[44] The Bosso section represents one of the first localities where the magnetostratigraphy of the JurassicCretaceous boundary has been documented. Lowrie and Channell [1984] compared the magnetostratigraphy of the lowermost $110 \mathrm{~m}$ of Maiolica at Bosso with biostratigraphic zonation made by Micarelli et al. [1977] using calpionellids. The calpionellid biozonation at Bosso was subsequently revised by Channell and Grandesso [1987]. Later, Bralower

Figure 12. Stratigraphic distance versus age correlation plot. The magnetic polarity zones from (a) Arcevia and (b) Bosso are correlated to polarity chrons from the GPTS. Polarity chron designations and age of polarity chrons are from Gradstein et al. [1994]. Sloping lines are average sediment accumulation rates. The Arcevia stratigraphic column is made by merging the upper and lower stratigraphic subsection and assuming a complete overlap of the arc $2 \mathrm{n}$ subzones. The displacements of the two faults from the lower stratigraphic subsection (Figure 3) are restored by considering both magnetostratigraphic and biostratigraphic evidence (see text). For the lowermost strata at Bosso, characterized by condensed sedimentation and/or hiatuses, no correlation with the GPTS is apparent (see text). 

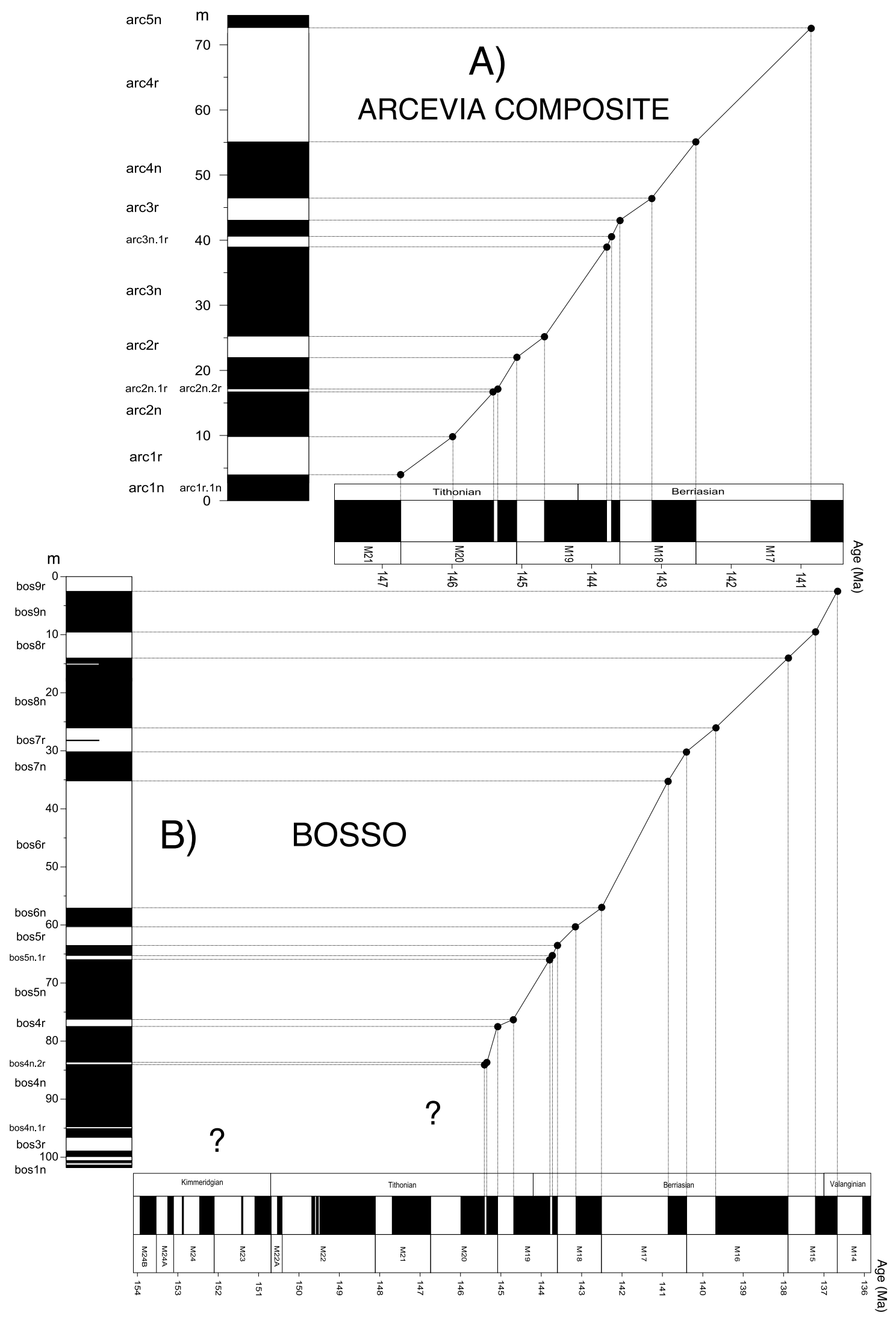

Figure 12 
Table 2. Meter Levels of Polarity Zone Boundaries, Lithologic Boundaries, and Nannofossil Events in Each Section ${ }^{\text {a }}$

\begin{tabular}{|c|c|c|c|c|c|c|}
\hline $\begin{array}{l}\text { Lithologic } \\
\text { Boundaries }\end{array}$ & $\begin{array}{c}\text { Nannofossil } \\
\text { Events }\end{array}$ & $\begin{array}{c}\text { Reversed } \\
\text { Polarity Zones } \\
\text { (Chrons) }\end{array}$ & $\begin{array}{c}\text { Arcevia } \\
\text { Composite, } \mathrm{m}\end{array}$ & $\begin{array}{c}\text { Bosso, } \\
\mathrm{m}\end{array}$ & $\begin{array}{c}\text { Contessa, } \\
\mathrm{m}\end{array}$ & $\begin{array}{c}\text { Gorgo a } \\
\text { Cerbara, m }\end{array}$ \\
\hline \multirow[t]{7}{*}{ Fucoidi marls/Maiolica } & & & & & & 82.70 \\
\hline & & top gor4r (M0) & & & & 81.64 \\
\hline & & base gor4r (M0) & & & & 79.96 \\
\hline & & top gor3r (M1) & & & & 60.83 \\
\hline & & base gor3r (M1) & & & & 54.65 \\
\hline & & top gor2r (M3) & & & & 45.15 \\
\hline & & base gor $2 r$, con $11 \mathrm{r}(\mathrm{M} 3)$ & & & 0.59 & 19.73 \\
\hline Top Faraoni guide bed & & & & & 8.32 & 11.02 \\
\hline \multirow{20}{*}{ Base Faraoni guide bed } & & & & & 8.52 & 10.82 \\
\hline & & top gor1r, con10r (M5) & & & 12.70 & 5.60 \\
\hline & & base con10r (M5) & & & 15.74 & \\
\hline & & top con9r (M6) & & & 17.46 & \\
\hline & & base con9r (M6) & & & 18.96 & \\
\hline & & top con8r (M7) & & & 21.54 & \\
\hline & & base con8r (M7) & & & 27.01 & \\
\hline & & top con7r (M8) & & & 30.58 & \\
\hline & & base con7r (M8) & & & 32.94 & \\
\hline & & top con6r (M9) & & & 36.70 & \\
\hline & & base con2r, bos9r (M14) & & 2.59 & 89.20 & \\
\hline & & top con1r, bos8r (M15) & & 9.39 & 93.78 & \\
\hline & & base con1r, bos8r (M15) & & 14.02 & 98.57 & \\
\hline & FAD Rucinolithus wisei & & & & 102.51 & \\
\hline & & top bos7r (M16) & & 26.04 & & \\
\hline & & base bos7r (M16) & & 30.22 & & \\
\hline & & top bos8r, arc4r (M17) & 72.40 & 35.16 & & \\
\hline & & base bos8r, arc4r (M17) & 54.90 & 57.00 & & \\
\hline & & top bos5r, arc3r (M18) & 46.27 & 60.42 & & \\
\hline & & base bos5r, arc3r (M18) & 42.85 & 63.50 & & \\
\hline \multirow[t]{13}{*}{ Maiolica/Calcari ad Aptici } & & & 42.85 & 82.90 & & \\
\hline & FAD Umbria granulosa & & 40.71 & & & \\
\hline & & $\begin{array}{l}\text { top bos5n.1r, arc3n.1r } \\
\text { (M19n-1) }\end{array}$ & 40.43 & 65.42 & & \\
\hline & & $\begin{array}{l}\text { base bos } 5 n .1 r \text {, arc3n.1r } \\
\text { (M19n-1) }\end{array}$ & 38.59 & 65.94 & & \\
\hline & FAD Nannoconus infans & & 34.66 & & & \\
\hline & FAD Cruciellipsis cuvillieri & & 28.26 & & & \\
\hline & & top bos4r, arc2r (M19) & 25.07 & 76.21 & & \\
\hline & FAD Rhagodiscus asper & & 22.24 & & & \\
\hline & & base bos4r, arc2r (M19) & 21.74 & 77.45 & & \\
\hline & & $\begin{array}{l}\text { top bos } 4 n .2 r, \operatorname{arc} 2 n .1 r \\
\quad \operatorname{arc} 2 n .2 r(M 20 n-1)\end{array}$ & 16.48 & 83.62 & & \\
\hline & & $\begin{array}{l}\text { base bos4n.2r, arc } 2 n .1 r \text {, } \\
\text { arc2n.2r (M20n-1) }\end{array}$ & 16.09 & 83.98 & & \\
\hline & & top arc1r (M20) & 9.31 & & & \\
\hline & & base $\operatorname{arc} 1 \mathrm{r}(\mathrm{M} 20)$ & 3.92 & & & \\
\hline
\end{tabular}

${ }^{a}$ Correlative polarity chron boundaries are shown in parentheses. Polarity chron nomenclature is after Gradstein et al. [1994]. All meter levels are calculated after restoring fault displacements. The Arcevia composite section is made by merging the upper and lower stratigraphic subsection and assuming a complete overlap of the arc2n subzones.

et al. [1989] framed the calcareous nannofossil stratigraphy within the magnetozones documented by Lowrie and Channell [1984]. Baumgartner [1987] studied the radiolarian of the cherty layers from both the lower part of the Maiolica and the Calcari ad Aptici. Finally, Housa et al. [2004] provided new magnetostratigraphic and calpionellid zonation data for the lowermost $28.5 \mathrm{~m}$ of Maiolica and uppermost $10.5 \mathrm{~m}$ of Calcari ad Aptici.
[45] The correlation of the magnetozones from Maiolica and upper Calcari ad Aptici at Bosso to polarity chrons was solidly established by Lowrie and Channell [1984] and Housa et al. [2004], so that our magnetozones bos4n to bos9r (Figure 5) can be correlated to chrons M20n to M14 (Figure 12b and Table 2). The subchrons M19n-1 and M20n-1, studied with great detail by Housa et al. [2004] are both represented by solely one reverse-polarity sample

Figure 13. Summary of the more important magnetostratigraphic studies of lower Cretaceous-upper Jurassic sections [e.g., Opdyke and Channell, 1996], correlation to the geomagnetic polarity timescale from Gradstein et al. [1994] and to magnetostratigraphic results from this study. All sections are in Italy, apart from Berrias (France) and Carcabuey (Spain). References are Gorgo a Cerbara-1, Contessa, Bosso-1, and Arcevia, this study; Monte Acuto, Channell et al. [1995a]; Gorgo a Cerbara-2, Frontale, Presale, Lowrie and Alvarez [1984]; Pié Dosso, Polaveno, Channell and Erba [1992]; Cismon, Channell et al. [1979]; Capriolo, Channell et al. [1987]; Bosso-2, Lowrie and Channell [1984]; Bosso-3, Housa et al. [2004]; Fonte del Giordano, Cirilli et al. [1984]; Berrias, Galbrun [1985]; Carcabuey, Ogg et al. [1984]; Xausa, Channell et al. [1987], Foza, Ogg [1981]; Quero and Frisoni, Channell and Grandesso [1987]. 


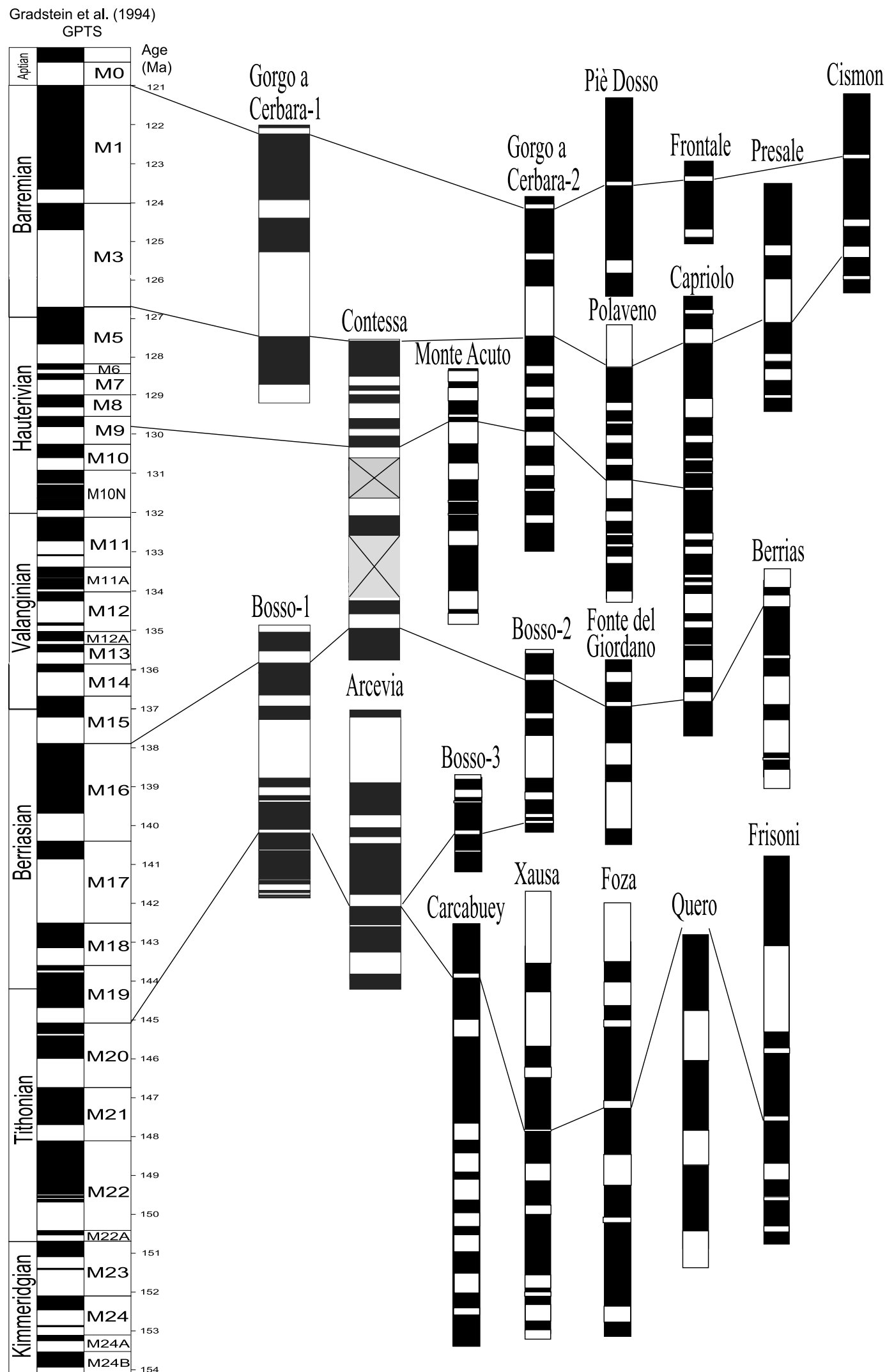

Figure 13 
in our data set. The sedimentation rate in the Maiolica limestones reaches the maximum value $(13.2 \mathrm{~m} / \mathrm{Myr})$ during chron M17, and decreases upsection to $6.7 \mathrm{~m} / \mathrm{Myr}$ (during chron M16n), and downsection to $11.3 \mathrm{~m} / \mathrm{Myr}$ (average from bottom of M18 to bottom of M20n-1, Figure 12b).

[46] The lowermost $8.5 \mathrm{~m}$ of Calcari ad Aptici (never magnetostratigraphically investigated before) reveal a continuous normal polarity zone (which according to Housa et al. [2004] can be correlated to the M20n chron), and a succession of thin ( 0.30 to $2.30 \mathrm{~m}$ thick) magnetozones in the lowermost $7 \mathrm{~m}$ of section (Figure 5). No correlation with the GPTS is apparent here, when the sedimentation rates observed in the Maiolica and uppermost part of Calcari ad Aptici are extrapolated (Figure 12b/11b). Baumgartner [1987] stated that the lowermost Calcari ad Aptici strata at Bosso belonged to the upper part of radiolarian zone B, which now corresponds to the "Unitary Association Zone" 9-10 (mid-Oxfordian-early Kimmeridgian according to Baumgartner et al. [1995]). We note that, according to the GPTS from GRAD94, the M20n chron (correlated to the bos4n zone at Bosso) falls within the Late Tithonian, implying an extreme condensation and/or hiatuses occurring in the lowermost $8 \mathrm{~m}$ of Calcari ad Aptici. We conclude that no correlation with the GPTS for chrons older than M20n can be established at Bosso (Figure 12b/11b).

\subsection{Contessa}

[47] No biostratigraphic data have been reported so far for the Maiolica exposed at Contessa. However, at $8.4 \mathrm{~m}$ we sampled the ammonite Faraoni guide level (Figures $6 \mathrm{a}$ and 7 and Table 2), constrained to the uppermost Hauterivian by Cecca et al. [1994b], and correlated to the polarity chron M5n by Channell et al. [1995a] at Bosso and Gorgo a Cerbara. At Contessa, we constrained the Faraoni ammonitic guide bed to $65 \%$ of chron M5n (calculated from the top of the chron).

[48] In order to have an age tie point for the lower part of the section, the calcareous nannofossil content of samples from the lowermost $13 \mathrm{~m}$ of section was determined. The interval comprised between the samples CON200 (meter 96.8) and CON226 (meter 109.5, bottom of the section) was analyzed. The samples from Contessa are all productive for nannofossils (except sample 202 that is barren), although overall abundances are quite low, and a relatively large surface of the slide $\left(0.06\right.$ to $\left.0.120 \mathrm{~cm}^{2}\right)$ should be studied, in order to achieve 100 specimens on average. A total of 39 species was recorded, with a species richness varying between 17 and 24 species/sample. Preservation was variable from one sample to another but the majority of samples displayed moderate preservation. Watznaueria barnesae is the dominant taxon (on average $39 \%$ of the total assemblage). This pattern is well known and discussed in the literature for different Cretaceous settings [see, e.g., Williams and Bralower, 1995]. The large-sized coccoliths of $W$. manivitae, which was the second dominant species in the Tithonian assemblages of Arcevia, display low relative abundances (1.7\% on average) at Contessa, A taxon that is quite abundant at Contessa is Cyclagelosphaera margerelii with average relative abundance of $19.64 \%$. The genus Nannoconus accounts for $11 \%$ of the total assemblages. Two other species are worth noticing: Watznaueria fossacincta and
Diazomatolitus lehmanii, that represent, respectively, 4.1\% and $4.15 \%$ of the assemblages.

[49] The First Occurrence of Rucinolithus wisei was recorded in sample CON212 (meter 102.5, Figures 7 and 14 and Table 2) and this taxon was systematically found in younger samples. This FO was reported by Bralower et al. [1989] in the middle part of M16n. Another species recorded in the Contessa samples, although rare, is Micrantholithus hoschulzii. Its FO was indicated by Bralower et al. [1989] in the M16n in two sections from central Italy (Bosso and Fonte del Giordano). These biostratigraphic data indicate a Berriasian age for the base of the Contessa section sampled in this work.

[50] The relatively high proportion of C. margerelii in the samples studied could be ecologically controlled. This taxon formed a significant component of nannofossil assemblages only at certain peculiar stratigraphical levels throughout the Jurassic and Cretaceous. High abundance, oligospecific assemblages formed by Cyclagelosphaera margerelii and Watznaueria britannica(=Ellipsagelosphaera communis of Busson et al. [1992]) were reported by Busson et al. [1992, 1993] in a Late Jurassic restricted lagoon environment, probably receiving freshwater influxes. High accumulation of Cyclagelosphaera margerelii also forms the light colored laminae of Kimmeridgian bituminous laminites (French Jura), interpreted as being deposited in a lagoonal environment with important salinity variations [Tribovillard et al., 1992]. Watznaueria britannica and Cyclagelosphaera margerelii also dominate in certain laminae of the English Kimmeridge Clay Formation (KCF) coccolith stone bands, probably indicating peculiar trophic conditions [Lees et al., 2004]. Such observations could provide new insight into the paleoenvironment in which sediments were formed in the Contessa area.

[51] At Contessa, well-resolved magnetozones could be retrieved only from the uppermost (above $40 \mathrm{~m}$ ) and lowermost (below $85 \mathrm{~m}$ ) parts of the section (Figure 7). Conversely, between 40 and $85 \mathrm{~m}$, most of the samples were found to be very weakly magnetized (below the noise level of the magnetometer), and the succession of magnetozones could not be satisfactorily resolved. Considering the magnetostratigraphic and biostratigraphic calibration point represented by the Faraoni guide level, the magnetozones from 0 to $40 \mathrm{~m}$ can be easily correlated to chrons M3 to M9 (Figure 15a). In fact, the distinctive pattern of our magnetozones con $10 \mathrm{n}$ to con $7 \mathrm{n}$ shows good correspondence with that observed for chrons M6n to M9n, respectively. Furthermore, considering the magnetozone sequence and the nannofossil assemblages observed in the lowermost $25 \mathrm{~m}$ of section, we correlate the magnetozones con2r to con $1 n$ to chrons M14 to M16n, respectively (Figure 15a/13a). Conversely, we are not able to find a convincing correlation for magnetozones from 40 to $85 \mathrm{~m}$, in the central part of the section. The sedimentation rate decreases from $11.8 \mathrm{~m} / \mathrm{Myr}$ in the upper $40 \mathrm{~m}$ of section (average from top of M5n to bottom of M9n) to $7.7 \mathrm{~m} /$ Myr in the lowermost $25 \mathrm{~m}$ (average from bottom of M14 to bottom of M15). This reduced sedimentation rate in these lower Maiolica strata is in agreement with the biostratigraphic information gathered from the lowermost $13 \mathrm{~m}$ of section.

[52] The finding of extremely weak remanence in the central part of the section may have two sources: (1) there 


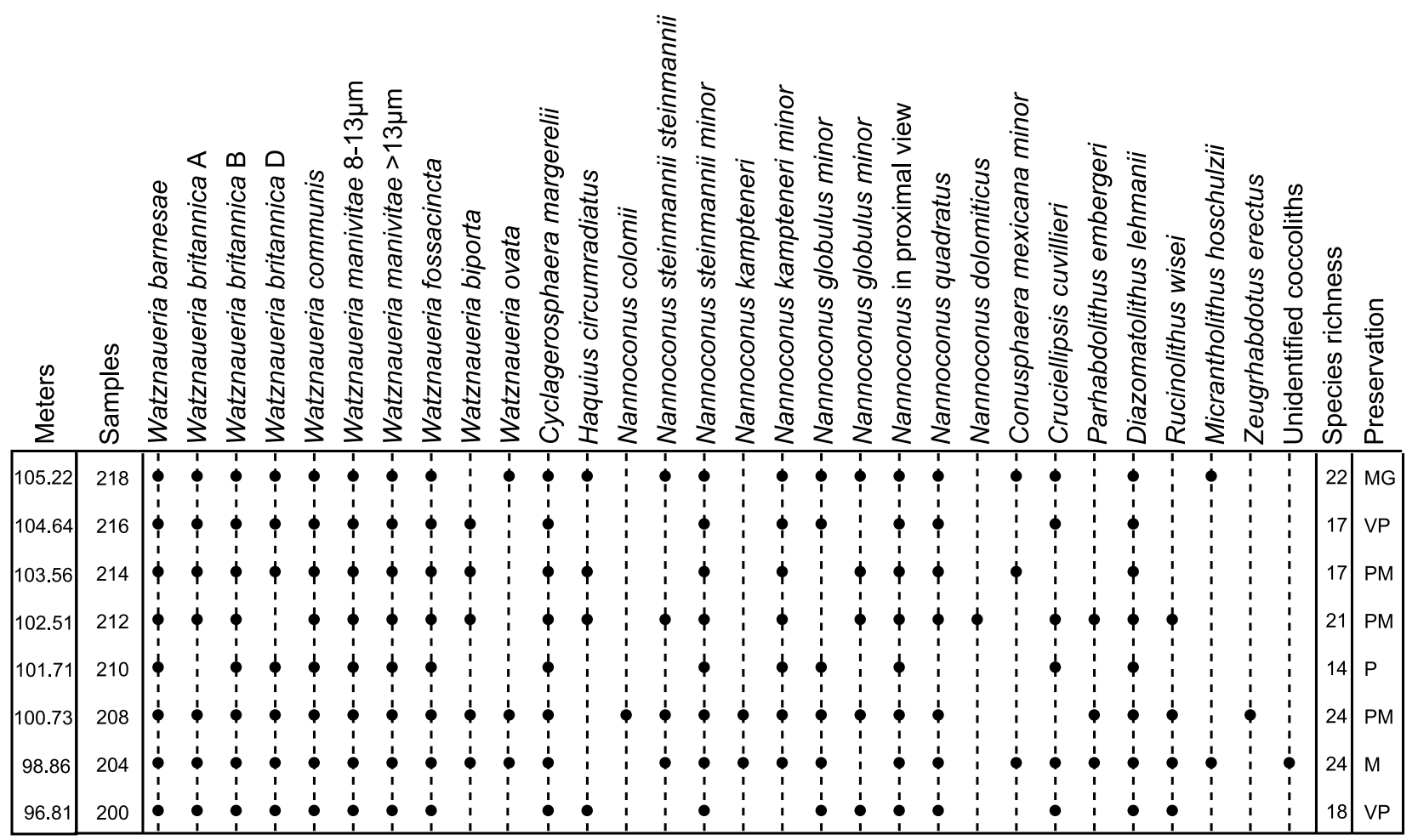

Figure 14. Distribution chart of calcareous nannofossils in the lower part of the Contessa section. The different morphotypes of Watznaueria britannica and the different sized Watznaueria manivitae are also reported. Preservation is discussed in the text.

are many faults cutting the section, which may have enabled fluid circulation and oxidation of magnetite and (2) the magnetostratigraphically failed Maiolica strata at Contessa are comprised between chrons M10n to M14, corresponding to the Lower Hauterivian- Lower Valanginian interval according to GRAD94. Yet a positive carbon isotope event has been constrained to the upper Valanginian (peaking in chrons $\mathrm{M} 10 \mathrm{~N}$ and M11) by several magnetostratigraphic investigations in the Maiolica exposed in northern Italy and Switzerland [Channell et al., 1993]. In those sections, a reduction in magnetization intensity coincident with the carbon isotope event is related to diagenetic magnetite dissolution enhanced by increased organic carbon burial. Likely, a similar diagenetic mechanism may have occurred in the Faraoni level (rich in organic matter), which we found to be not magnetized either at Contessa or Gorgo a Cerbara.

[53] Magnetostratigraphic data from Contessa concur with previous evidence from Bosso [Lowrie and Channell, 1984; Channell et al., 1995a], and indicate a "magnetostratigraphic recording gap" for the Umbria-Marche Maiolica from chron M10n to M14. However, at Fonte del Giordano and Monte Acuto, Cirilli et al. [1984] and Channell et al. [1995a] correlated their magnetozones to chrons M8 to M11n and M7 to M11, respectively (Figure 13). Cirilli et al. [1984] also documented a magne- tozone corresponding to chron M14n. Consequently, the Maiolica recording gap may be reduced to chrons M11 to $\mathrm{M} 14 \mathrm{n}$, that is from the upper Upper Valanginian to the upper Lower Valanginian, following GRAD94. We note that in the southern Alps the Maiolica strata sampled both at Capriolo [Channell et al., 1987] and Polaveno [Channell et al., 1995a] successfully record the M11 to M14n polarity chron interval, whilst the Pusiano section [Channell et al., 1993] show very low magnetization intensities and poor definition of polarity zones in such interval. We conclude that the M11-M14n magnetostratigraphic recording gap seems to represent a ubiquitous feature of the Maiolica deposited in the Umbria-Marche basin, while it is sporadically observed in the sections from the southern Alps.

\subsection{Gorgo a Cerbara}

[54] In the Maiolica at Gorgo a Cerbara, the nannofossil content was documented by Lowrie et al. [1980], Coccioni et al. [1992], Cecca et al. [1994a], and Channell et al. [1995a, 2000], the planktonic foraminifera distribution by Coccioni et al. [1992] and Cecca et al. [1994a], while ammonite finds were reported by Cecca et al. [1994a, 1994b] and Channell et al. [1995a].

[55] The magnetozones observed by us in the $82 \mathrm{~m}$ of sampled Maiolica at Gorgo a Cerbara (Figure 9) can be

Figure 15. Stratigraphic distance versus age correlation plot. The magnetic polarity zones from (a) Contessa and (b) Gorgo a Cerbara are correlated to polarity chrons from the GPTS. Polarity chron designations and age of polarity chrons are from Gradstein et al. [1994]. Sloping lines are average sediment accumulation rates. No correlation with the GPTS was attempted in the central part of the Contessa section, due to the great number of failed (very weakly magnetized) samples and poor magnetozone definition. 


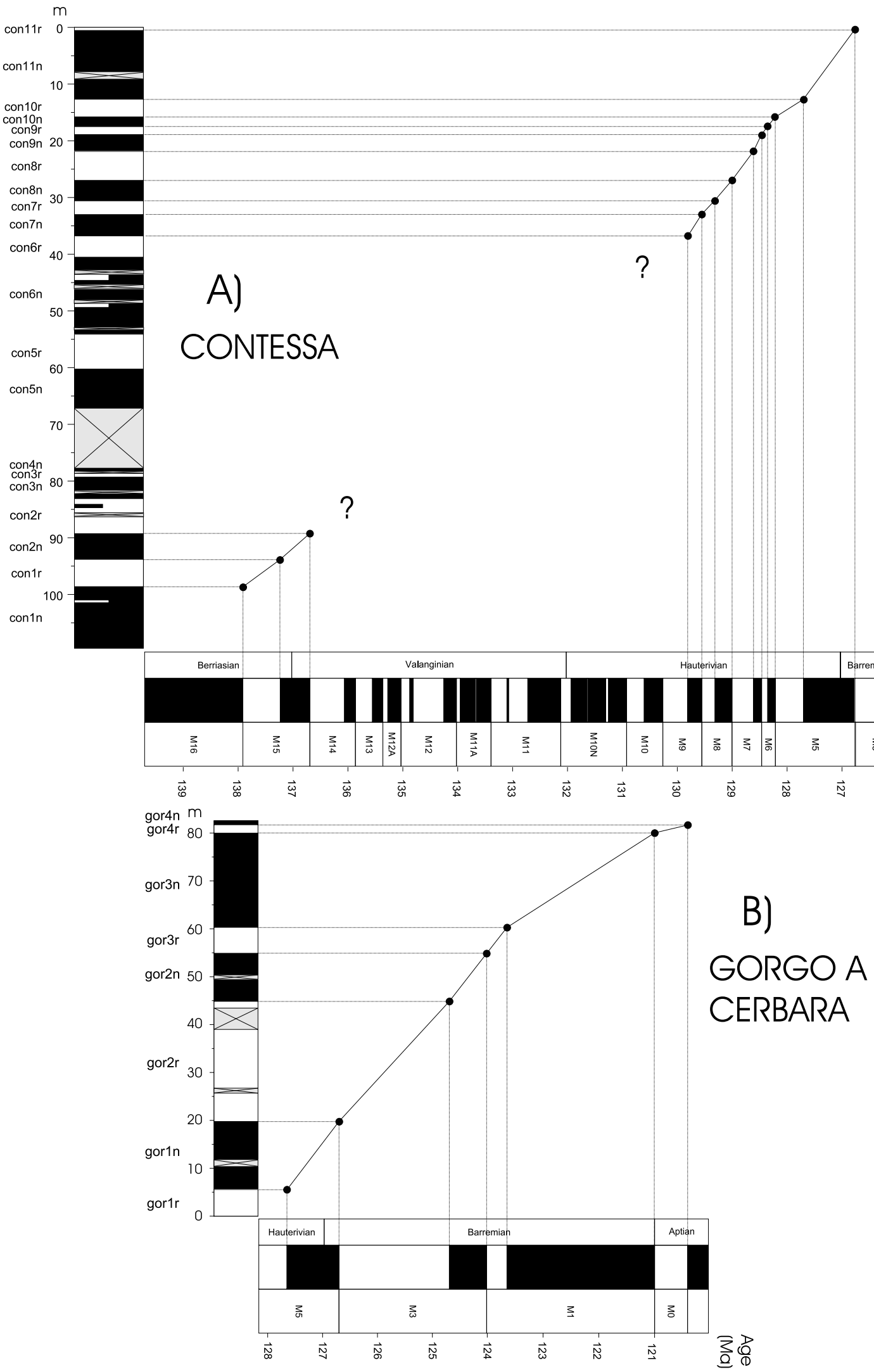

Figure 15 
safely correlated to chrons C34n to M5 (Figure 15b/13b and Table 2), as the same strata were magnetostratigraphically studied by Lowrie et al. [1980], Lowrie and Alvarez [1984], and Channell et al. [2000]. The Faraoni level falls within chron M5n, as previously documented by Channell et al. [1995a]. We constrained the Faraoni ammonitic guide bed to $62 \%$ of chron M5n (from the top of the chron), which is virtually identical to the stratigraphic position documented at Contessa by us and at Bosso by Channell et al. [1995a]. The sedimentation rate decreases moving upsection, from $13.8 \mathrm{~m} / \mathrm{Myr}$ (average from bottom of M1n to bottom of M5n), to $7.2 \mathrm{~m} / \mathrm{Myr}$ during chron M1n, and finally to 2.8 (or 4.3) $\mathrm{m} / \mathrm{Myr}$ during chron M0 (using the GPTS from GRAD94 or Gradstein et al. [2005], respectively, Figure $15 \mathrm{~b}$ ). Thus the sedimentation rate strongly decreases (by almost one order of magnitude, if the GRAD94 scale is considered) in the upper part of the Maiolica limestones, when approaching the boundary with the Fucoidi marls. The decrease seems to be progressive and to start within chron M1n.

\section{Details of the Polarity Subchrons and Geomagnetic Excursions}

[56] The overall data set of 861 cores from the Arcevia, Bosso, Contessa, and Gorgo a Cerbara sections encompasses the whole Maiolica and Calcari ad Aptici successions, and yields a continuous record of polarity chrons, from M21n to M14 and from M9 to M0 (Figure 13). The succession of magnetozones identified by us fully confirms the sequence of M polarity chrons as inferred from oceanic magnetic anomaly analysis [GRAD94, Channell et al., 1995b; Gradstein et al., 2005]. Arcevia represents the land section with the highest sedimentation rates reported so far for chrons M20 to M19n, and yields an unprecedented, expanded record of the short polarity subchrons M20n-1 and M19n-1. After additional detailed sampling, we found at Bosso two intervals (within two different magnetozones) showing VGPs departing by more than $45^{\circ}$ from the mean (normal or reverse polarity) paleomagnetic pole of the section. These data may suggest that an excursion and a reversal excursion of the geomagnetic field occurred during chrons M16n and M16, respectively.

\subsection{M20n-1 and M19n-1 Subchrons at Arcevia}

[57] At Arcevia, the polarity subzones arc2n.1r and arc2n.2r (Figure 3) are both inferred to represent the polarity subchron M20n-1 (Figure 12a), duplicated by a normal fault (Figures 16a and 16b). This is the third land section apart from Brodno [Housa et al., 1999] and Bosso [Housa et al., 2004] documenting such short-duration feature of the GPTS. Arc2n.1r and $\operatorname{arc} 2 \mathrm{n} .2 \mathrm{n}$ are 44 and $34 \mathrm{~cm}$ thick, respectively (Figures $16 \mathrm{~b}$ and $16 \mathrm{a}$ ), while the subzones corresponding to M20n-1 from Brodno and Bosso are 15 and $17 \mathrm{~cm}$ thick, respectively. Therefore Arcevia is characterized by a sedimentation rate during the subchron M20n-1 roughly double those of Brodno and Bosso. The zone arc2n (correlated to chron M20n) exposed in the lower stratigraphic subsection is $15.5 \mathrm{~m}$ thick (Figure 3), which has to be reduced to $12.0 \mathrm{~m}$ (translating to a sedimentation rate of $13.2 \mathrm{~m} / \mathrm{Myr}$ ) when the $3.5 \mathrm{~m}$ duplication by the fault located between $\operatorname{arc} 2 \mathrm{n} .1 \mathrm{r}$ and $\operatorname{arc} 2 \mathrm{n} .2 \mathrm{r}$ is taken into account
(Figure 12a). By assuming a uniform sedimentation rate during chron M20n, our data indicate that the subchron M20n-1 (considering an average thickness of $39 \mathrm{~cm}$ ) represents $3.2 \%$ the time of duration of M20n. We note that both the GPTS from GRAD94 and Channell et al. [1995b] (obtained by different oceanic magnetic anomaly block models) suggest an almost double duration for M20n1 , which is constrained to represent $6.6 \%$ and $5.2 \%$ of chron $\mathrm{M} 20 \mathrm{n}$ in time, respectively. Moreover, the duration of subchron M20n-1 evaluated by us at Arcevia must be retained as a maximum value, because we assumed that the $\operatorname{arc} 2 \mathrm{n}$ zones from the upper and lower subsection (Figure 3) are in complete overlap.

[58] Both layers recording the subchron M20n-1 reveal that it is characterized by a reversal excursion (following the terminology adopted by Abdul Aziz and Langereis [2004]), with individual VGP values deviating by $94^{\circ}$ and $157^{\circ}$ from the mean (reverse polarity) paleomagnetic pole of the section (Figures 16a and 16b). This feature has never been documented so far either by oceanic magnetic anomaly or land magnetostratigraphic data.

[59] The M19n-1 subchron (corresponding to the polarity subzone arc3n.1r in Figure 3) is also documented at Arcevia for the third time in a land section (Figures 3 and 12a), after Brodno and Bosso. However, the thickness of M19n-1 documented at Arcevia $(1.8 \mathrm{~m})$ is far greater with respect to those at Brodno (24 cm [Housa et al., 1999]) and Bosso (77 cm [Housa et al., 2004]. The arc3n zone (corresponding to chron M19n) is $17.8 \mathrm{~m}$ thick (Figure 3). Thus, assuming a constant sedimentation rate during chron M19n, our data indicate that the duration of the subchron M19n-1 is $10.1 \%$ that of M19n. This value proves to be significantly greater, this time, than the two corresponding values proposed by GRAD94 and Channell et al. [1995b] (6.5\% and 6.9\%, respectively). The exceptionally expanded record of subchron M19n-1 shows that it is not characterized by any geomagnetic excursion, and that its lower polarity transition is significantly longer and may last twice as long as the upper polarity recovery to M19n (Figure 3).

\subsection{Geomagnetic Excursions Within Chrons M16n and M16 at Bosso}

[60] At Bosso, within the upper part of the bos8n zone, correlated with chron M16n (Figure 12b), two VGPs deviating by more than $45^{\circ}$ from the mean paleomagnetic pole of the section are observed after additional detailed sampling (Figure 16c). These data may suggest a geomagnetic excursion occurring at $31 \%$ of chron M16n (calculated from its top), confined within $\sim 50 \mathrm{~cm}$ of Maiolica limestones. By considering the sedimentation rate at Bosso within chron M16n using the GRAD94 GPTS $(6.7 \mathrm{~m} / \mathrm{Myr})$, the excursion is inferred to last $\sim 70 \mathrm{kyr}$.

[61] Within the underlying bos $7 \mathrm{r}$ zone (correlated to chron M16), a VGP deviating by $160^{\circ}$ from the mean (reverse polarity) paleomagnetic pole of the section, and three additional VGPs deviating between $45^{\circ}$ and $85^{\circ}$ are observed (Figure $16 \mathrm{~d} / 14 \mathrm{~d}$ ). The two samples deviating by $85^{\circ}$ and $160^{\circ}$ are separated by two samples deviating by $13^{\circ}$ and $14^{\circ}$, suggesting a twofold excursion event. The transitional directions span about one third of the duration of the M16 chron, and the fact that one sample deviates by more than $90^{\circ}$ implies that this event should be termed a reversal excursion. 

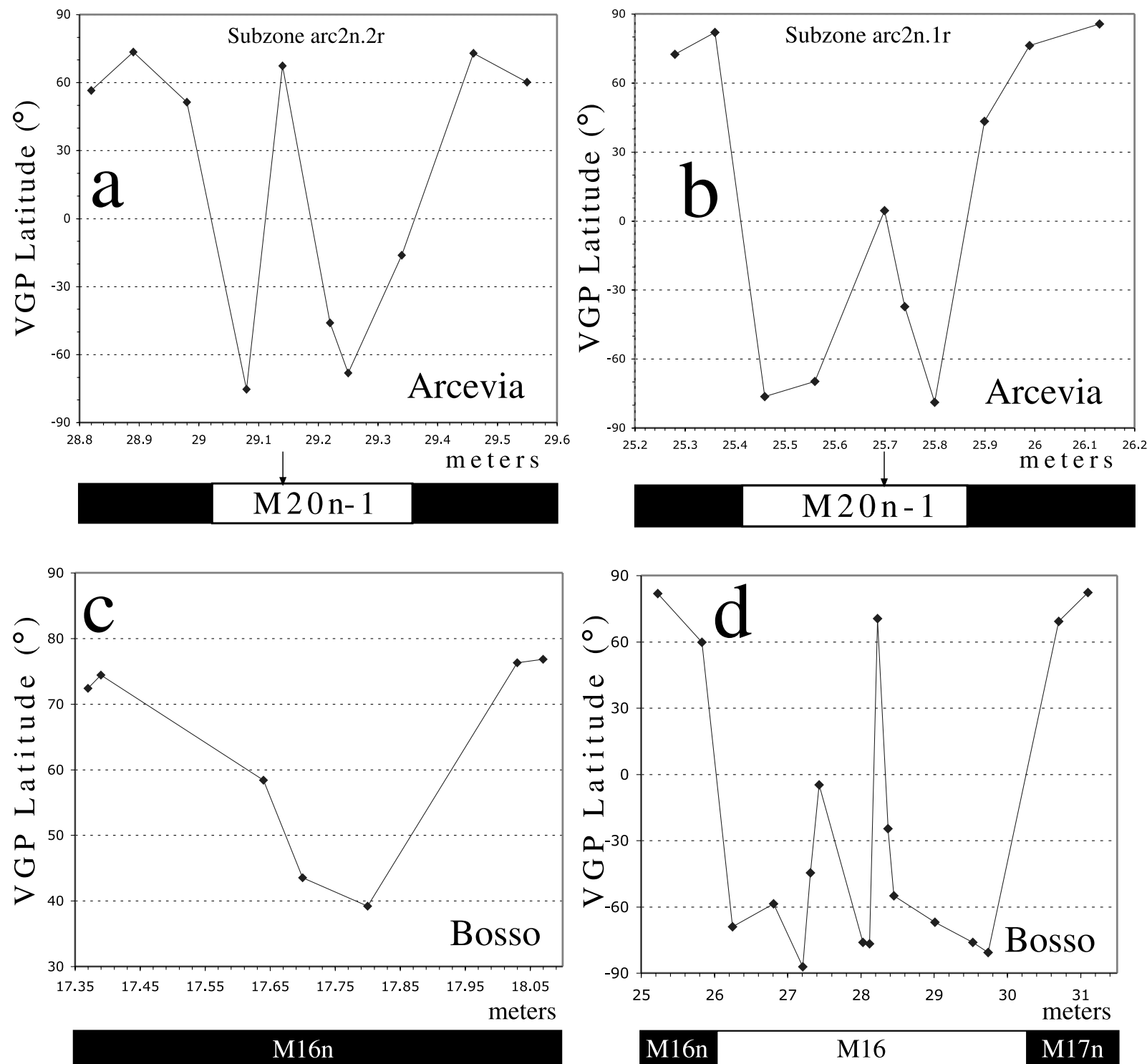

\section{M16n}

Figure 16. Detail of VGP latitudes $(a-b)$ for Arcevia with polarity chron interpretation between level 29.6 and $25.2 \mathrm{~m}$ of the lower stratigraphic subsection, and $(\mathrm{c}-\mathrm{d})$ for Bosso with polarity chron interpretation between levels 17.35 and $31.5 \mathrm{~m}$. Meter levels are as in Figures 3 and 5, respectively. At Arcevia the two reverse-polarity subzones arc2n.2r (Figure 16) and arc2n.1r (Figure 16) are correlated to the same subchron M20n-1, duplicated by a normal fault. The arrows indicate the position of the samples pointing to a reversal excursion within subchron M20n-1.

[62] It may be argued that the geomagnetic excursions we document at Bosso and Arcevia are in fact due to partial or complete magnetic overprint phenomena. Yet, no evidence has been provided (by our and previous studies) for remagnetization occurring at Bosso and Arcevia, and the samples displaying departures by more than $45^{\circ}$ from the mean paleomagnetic pole do not display anomalous demagnetization data.

[63] At Contessa we observed a sample (CON209) within the con1n zone (correlated with chron M16n) deviating by $124^{\circ}$ from the mean pole of the section. We suspected that this datum might represent the same excursion observed at Bosso within chron M16n, and we drilled seven additional cores in the layers in proximity to CON209. Yet, all these new samples evidenced only a normal polarity and VGPs almost coincident with the mean pole of the section (Figure 7), suggesting that CON209 may in fact be an outlier. However, when we extrapolated the position of the excursion observed at Bosso within chron M16n to Contessa (taking account of the respective sedimentation rates), we found a position $(102.85 \mathrm{~m})$ which is very close to the actual position of sample CON209 (101.2 m). Though the level is not identical, it must be considered that the bottom of chron M16n was not reached at Contessa, and that the excursion from Bosso was extrapolated by considering the sedimentation rate evaluated from chrons M15 and M15n at Contessa. To sum up, we regard the data from Contessa as not conclusive to confirm (or not) the existence of the geomagnetic excursion within chron M16n found at Bosso: there is only one datum from Contessa pointing 
to a reversal excursion, yet its relative position within chron M16n is very similar to the anomalous samples from Bosso.

[64] The excursions observed by us within chrons M16n and M16 at Bosso were not reported by Lowrie and Channell [1984], likely due to the wider sampling spacing they adopted. Moreover their study aimed at defining the magnetic stratigraphy at Bosso, instead of the second-order features of the geomagnetic field. Magnetostratigraphic data from chrons M16n and M16 were also gathered from Fonte del Giordano (close to Bosso [Cirilli et al., 1984] (Figure 13)), Berrias (France, Galbrun, 1985), Xausa, Frisoni, Valle del Mis (northern Italy [Channell and Grandesso, 1987]), Capriolo (northern Italy [Channell et al., 1987]), Cehegin (Spain [Ogg et al., 1988]), and Polaveno (northern Italy [Channell et al., 1995a]).

[65] It should be noted that at Xausa two reverse-polarity samples are reported within the upper part of chron M16n, and at Berrias a VGP latitude of $\sim 45^{\circ}$ is observed in the upper part of chron M16n. Similarly, at Frisoni, where chron M16 is considerably expanded ( $\sim 23 \mathrm{~m})$, many VGPs deviate between $45^{\circ}$ and $90^{\circ}$ from the mean reverse-polarity pole of the section, and at Fonte del Giordano a VGP deviating by $\sim 40^{\circ}$ from the mean reverse-polarity pole of the section can be observed within chron M16. Therefore the data from Fonte del Giordano [Cirilli et al., 1984], Berrias [Galbrun, 1985], Frisoni and Xausa [Channell and Grandesso, 1987] seem to concur with our data from Bosso and support the occurrence of geomagnetic excursions within chrons M16n and M16. Similar evidence may have been lacking in other sections due to smaller sedimentation rates and/or wider sampling spacing.

\section{Conclusions}

[66] The magnetostratigraphic investigation of the Maiolica and Calcari ad Aptici limestones from the Arcevia, Bosso, Contessa, and Gorgo a Cerbara land sections (Umbria-Marche, Italy) has provided a detailed record of polarity chrons M21n to M14 and M9 to M0. Though we sampled the Maiolica from Umbria-Marche more densely than in the past, we observed no difference (i.e., no new subchrons or microchrons) with respect to the sequence of $\mathrm{M}$ polarity chrons inferred from oceanic magnetic anomaly profiles [GRAD94; Channell et al., 1995b].

[67] At Contessa, the Maiolica deposited from chrons M14 to M10n was found to be very weakly magnetized (often below the noise level of the magnetometer, i.e., $<5 \mu \mathrm{A} / \mathrm{m}$ ), confirming similar evidence gathered in the past at Bosso [Lowrie and Channell, 1984]. Considering also data from other sections [Cirilli et al., 1984; Channell et al., 1995a] we find that the Maiolica from Umbria-Marche is characterized by a magnetostratigraphic "recording gap" between chrons M14n to M11, possibly due to diagenetic magnetite dissolution related to the Late Valanginian carbon isotope event [Channell et al., 1993]. In the southern Alps, the Pusiano section [Channell et al., 1993] shows the same recording gap as in Umbria-Marche, while the Maiolica exposed at Capriolo [Channell et al., 1987] and Polaveno [Channell et al., 1995a] displays normal records of the M14n-M11 polarity chrons.

[68] Arcevia proves to be the most expanded land section documented so far for the interval between the top of chron
M19n and the bottom of M20, recorded within abnormally thick $(43 \mathrm{~m})$ Calcari ad Aptici strata. Here the boundary between the Maiolica and Calcari ad Aptici limestones occurs at the top of chron M19n, while at Bosso it has been constrained in the upper part of chron M20n by both Housa et al. [2004] and our data. We conclude that the onset of Maiolica sedimentation may be diachronous by $1.5-2$ Myr within the Umbria-Marche domain, and influenced by local patterns of carbonate production superimposed on regional trends. Moreover, at Arcevia we observed the highest sedimentation rate (of the whole of our data set) within the upper part of the Calcari ad Aptici (16.5 m/Myr during chron M19n), and smaller values in the overlying Maiolica $(10.8 \mathrm{~m} / \mathrm{Myr})$. Conversely, at Bosso, the sedimentation is extremely low in the markedly condensed lower Calcari ad Aptici strata, and progressively increases moving upsection to the Maiolica.

[69] After Brodno (western Slovakia [Housa et al., 1999]) and Bosso, Arcevia is the third land section documenting both the M20n-1 and M19n-1 subchrons. The corresponding polarity subzones are 0.39 and $1.8 \mathrm{~m}$ thick (respectively), i.e., twice (or more) thicker than corresponding subzones from Brodno and Bosso. Assuming constant sedimentation rates at Arcevia during chrons M20n and M19n, the duration of the M20n-1 and M19n-1 subchrons is found to be $3.2 \%$ and $10.1 \%$ of chrons M20n and M19n, respectively. These values are smaller and greater (respectively) than corresponding values reported for M20n-1 and M19n-1 by both GRAD94 and Channell et al. [1995b] GPTSs. Evidence can also be found for a reversal excursion occurring within the M20n-1subchron, while no transitional field was observed within the exceptionally expanded subzone $(1.8 \mathrm{~m})$ correlated to the M19n-1 subchron.

[70] At Bosso, evidence can be found for a geomagnetic excursion and a reversal excursion occurring within chrons M16n and M16, respectively. The 20-cm-thick calcareous guide bed of the uppermost Hauterivian "Faraoni" guide level is constrained to $65 \%$ and $62 \%$ of chron M5n (calculated from the top of the chron) at Contessa and Gorgo a Cerbara, respectively, in agreement with previous evidence from Bosso [Channell et al., 1995a].

[71] Acknowledgments. Thanks are due to the Mancini Group and Fratelli Vispi for allowing us to collect samples from the active quarries at Arcevia and Contessa, respectively. The help given by L. Angelelli at Arcevia is particularly acknowledged. Discussions with A. Bartolini, F. Cecca, M. Cobianchi, G. Parisi, A. Marini, and J. Dinarès were much appreciated. Many thanks E. Boschi for encouragement to the owners of the "Locanda del Castello" for having sheltered us in the wonderful Frontone fortress. F.S. also wishes to thank Ilary Blasi for the kind present received at Frontone Digital elevation model data of the northern Apennines were downloaded by F. D'Ajello from the U.S. Geological Survey's EROS Data Center, NASA Jet Propulsion Laboratory, California Institute of Technology. S.S. and F.C. were financially supported by MIUR grants (awarded to F.C.). We are grateful to the referees James E. T. Channell and James G. Ogg for providing thorough reviews of the manuscript and to the Associate Editor Randolph Enkin and the Editor Richard Arculus for carefully evaluating our work.

\section{References}

Abdul Aziz, H., and C. G. Langereis (2004), Astronomical tuning and duration of three new subchrons (C5r.2r-1n, C5r.2r-2n and C5r.3r-1n) recorded in a middle Miocene continental sequence from NE Spain, in Timescales of the Paleomagnetic Field, Geophys. Monogr. Ser., vol. 145, edited by J. E. T. Channell et al., pp. 141-160, AGU, Washington, D. C.

Alvarez, W., M. A. Arthur, A. G. Fisher, W. Lowrie, G. Napoleone, I. Premoli Silva, and W. Roggenthen (1977), Late Cretaceous-Paleocene 
geomagnetic reversal time scale: V. Type section in the pelagic limestone sequence at Gubbio, Italy, Geol. Soc. Am. Bull., 88, 383-389.

Baudin, F., P. Faraoni, A. Marini, and G. Pallini (1997), Organic matter characterisation of the "Faraoni Level" from northern Italy (Lessini Mountains and Trento Plateau): Comparison with that from UmbriaMarche Apennines, Palaeopelagos, 7, 41-51.

Baumgartner, P. O. (1987), Genesis of Jurassic Tethyan radiolarites - The example of Monte Nerone (Umbria-Marche Apennines), paper presented at the II International "Fossili, Evoluzione, Ambiente" Congr., Pergola, Italy.

Baumgartner, P. O., L. O’Dogherty, S. Gorican, E. Urquhart, A. Pillevuit, and P. De Wever (Eds.) (1995), Middle Jurassic to Lower Cretaceous Radiolaria of Tethys: Occurrences, Systematics, Biochronology, Mém. Géol., 23, 1172 pp.

Bornemann, A., U. Aschwer, and J. Mutterlose (2003), The impact of calcareous nannofossils on the pelagic carbonate accumulation across the Jurassic/Cretaceous boundary, Palaeogeogr. Palaeoclimatol. Palaeoecol., 199, 187-228.

Bown, P. R., and M. K. E. Cooper (1998), Jurassic, in Calcareous Nannofossil Biostratigraphy, edited by P. R. Bown, pp. 34-54, Cambridge Univ. Press, New York.

Bralower, T. J., S. Monechi, and H. R. Thierstein (1989), Calcareous nannofossil zonation of the Jurassic-Cretaceous boundary interval and correlation with the geomagnetic polarity timescale, Mar. Micropaleontol., 14, $153-235$.

Busson, G., D. Noël, and A. Cornée (1992), Les coccolithes en "boutons de manchette" et la genèse des calcaires lithographiques du Jurassique supérieur, Rev. Paleobiol., 11, 255-271.

Busson, G., D. Noël, D. Contini, A.-M. Mangin, A. Cornée, and P. Hantzpergue (1993), Omniprésence de coccolithes dans des calcaires lagunaires du Jurassique moyen et supérieur de France, Bull. Cent. Rech. Explor. Prod. Elf Aquitaine, 17, 291-301.

Cecca, F., S. Cresta, G. Pallini, and M. Santantonio (1987), Il Giurassico di Monte Nerone (Appennino marchigiano, Italia Centrale): Biostratigrafia, litostratigrafia ed evoluzione paleogeografica, paper presented at the II International "Fossili, Evoluzione, Ambiente" Congress, Pergola, Italy.

Cecca, F., G. Pallini, E. Erba, I. Premoli Silva, and R. Coccioni (1994a), Hauterivian-Barremian chronostratigraphy based on ammonites, nannofossils, planktonic foraminifera and magnetic chrons from the Mediterranean domain, Cretaceous Res., 15, 457-467.

Cecca, F., A. Marini, G. Pallini, F. Baudin, and V. Begouen (1994b), A guide-level of the uppermost Hauterivian (Lower Cretaceous) in the pelagic succession of the Umbria-Marche Apennines (central Italy): the Faraoni level, Riv. Ital. Paleontol. Stratigr, 99, 551-568.

Channell, J. E. T., and E. Erba (1992), Early Cretaceous polarity chrons CM0 to CM11 recorded in northern Italian land sections near Brescia Earth Planet. Sci. Lett., 108, 161-179.

Channell, J. E. T., and P. Grandesso (1987), A revised correlation of Mesozoic polarity chrons and calpionellid zones, Earth Planet. Sci. Lett., $85,222-240$

Channell, J. E. T., and C. McCabe (1994), Comparison of magnetic hysteresis parameters of unremagnetized and remagnetized limestones, J. Geophys. Res., 99, 4613-4623.

Channell, J. E. T., W. Lowrie, and F. Medizza (1979), Middle and Early Cretaceous magnetic stratigraphy from the Cismon section, northern Italy, Earth Planet. Sci. Lett., 42, 133-166.

Channell, J. E. T., W. Lowrie, P. Pialli, and F. Venturi (1984), Jurassic magnetic stratigraphy from Umbrian (Italian) land sections, Earth Planet Sci. Lett., 68, 309-325.

Channell, J. E. T., T. J. Bralower, and P. Grandesso (1987), Biostratigraphic correlation of Mesozoic polarity chrons CM1 to CM23 at Capriolo and Xausa (Southern Alps, Italy), Earth Planet. Sci. Lett., 85, $203-$ 221

Channell, J. E. T., E. Erba, and A. Lini (1993), Magnetostratigraphic calibration of the Late Valanginian carbon isotope event in pelagic limestones from northern Italy and Switzerland, Earth Planet. Sci. Lett., $118,145-166$

Channell, J. E. T., F. Cecca, and E. Erba (1995a), Correlation of Hauterivian and Barremian (Early Cretaceous) stage boundaries to polarity chrons, Earth Planet. Sci. Lett., 134, 125-140.

Channell, J. E. T., E. Erba, M. Nakanishi, and K. Tamaki (1995b), Late Jurassic-Early Cretaceous time scales and oceanic magnetic anomaly block models, in Geochronology Time Scales and Global Stratigraphic Correlation, SEPM Spec. Publ., 54, 51-63.

Channell, J. E. T., E. Erba, G. Muttoni, and F. Tremolada (2000), Early Cretaceous magnetic stratigraphy in the APTICORE drill core and adjacent outcrop at Cismon (Southern Alps, Italy), and correlation to the proposed Barremian-Aptian boundary stratotype, Geol. Soc. Am. Bull., $112,1430-1443$.
Cirilli, S., P. Marton, and L. Vigliotti (1984), Implications of a combined biostratigraphic and palaeomagnetic study of the Umbrian Maiolica Formation, Earth Planet. Sci. Lett., 69, 203-214.

Coccioni, R., E. Erba, and I. Premoli-Silva (1992), Barremian-Aptian calcareous plankton biostratigraphy from the Gorgo a Cerbara section (Marche, central Italy) and implications for plankton evolution, Cretaceous Res., 13, 517-537.

Consiglio Nazionale delle Ricerche (1991), Progetto finalizzato geodinamica. structural model of Italy map, scale 1:500,000, edited by G. Bigi et al., Rome.

Galbrun, B. (1985), Magnetostratigraphy of the Berriasian stratotype section (Berrias, France), Earth Planet. Sci. Lett., 74, 130-136.

Giraud, F., S. Renaud, B. Pittet, E. Mattioli, and V. Audouin (2003), Variations de la morphologie et de l'abondance chez Watznaueria britannica (coccolithophoridés) en relation avec les paramètres paléoenvironnementaux au Jurassique, paper presented at 3ème Symposium de Morphométrie et évolution des formes, Groupement de Rech., Cent. de la Natl. Rech. Sci., Paris, 13 and 14 March.

Gradstein, F. M., F. P. Agterberg, J. G. Ogg, J. Hardenbol, P. van Veen, J. Thierry, and Z. Huang (1994), A Mesozoic time scale, J. Geophys. Res., 99, 24,051-24,074.

Gradstein, F. M., et al. (2005), A Geologic Time Scale 2004, 610 pp., Cambridge Univ. Press, New York.

Hay, W. W. (1972), Probabilistic stratigraphy, Eclogae Geol. Helv., 65, $255-266$.

Housa, V., M. Krs, M. Krsova, O. Man, P. Pruner, and D. Venhodova (1999), High-resolution magnetostratigraphy and micropalaeontology across the $\mathrm{J} / \mathrm{K}$ boundary strata at Brodno near Zilina, western Slovakia: summary of results, Cretaceous Res., 20, 699-717.

Housa, V., M. Krs, O. Man, P. Pruner, D. Venhodova, F. Cecca, G. Nardi, and M. Piscitello (2004), Combined magnetostratigraphic, palaeomagnetic and calpionellid investigations across Jurassic/Cretaceous boundary strata in the Bosso Valley, Umbria, central Italy, Cretaceous Res., 25, $771-785$.

Istituto Nazionale di Geofisica e Vulcanologia (2001), Italian Magnetic Network and Geomagnetic field maps of Italy at year 2000.0, Boll. Geod. Sci. Affini, 60 .

Kirschvink, J. L. (1980), The least-square line and plane and the analysis of paleomagnetic data, Geophys. J. R. Astron. Soc., 62, 699-718.

Lees, J. A., P. R. Bown, J. R. Young, and J. B. Riding (2004), Evidence for annual records of phytoplankton productivity in the Kimmeridge Clay Formation coccolith stone bands (Upper Jurassic, Dorset, UK), Mar. Micropaleontol., 52, 29-49.

Lowrie, W., and W. Alvarez (1984), Lower Cretaceous magnetic stratigraphy in Umbrian pelagic limestone sections, Earth Planet. Sci. Lett., 71, $315-328$.

Lowrie, W., and J. E. T. Channell (1984), Magnetostratigraphy of the Jurassic-Cretaceous boundary in the Maiolica limestone (Umbria, Italy), Geology, 12, 44-47.

Lowrie, W., W. Alvarez, I. Premoli Silva, and S. Monechi (1980), Lower Cretaceous magnetic stratigraphy in Umbrian pelagic carbonate rocks, Geophys. J. R. Astron. Soc., 60, 263-281.

Lowrie, W., W. Alvarez, G. Napoleone, K. Perch-Nielsen, I. Premoli Silva, and M. Toumarkine (1982), Paleogene magnetic stratigraphy in Umbrian pelagic carbonate rocks: The Contessa sections, Gubbio, Geol. Soc. Am. Bull., 93, 414-432.

McFadden, P. L., and M. W. McElhinny (1990), Classification of the reversal test in palaeomagnetism, Geophys. J. Int., 103, 725-729.

Micarelli, A., M. Potetti, and M. Chiocchini (1977), Ricerche microbiostratigrafiche sulla Maiolica della regione umbro-marchigiana, Stud. Geol. Camerti, 3, 57-86.

Morettini, E., M. Santantonio, A. Bartolini, F. Cecca, P. O. Baumgartner, and J. C. Hunziker (2002), Carbon isotope stratigraphy and carbonate production during the Early-Middle Jurassic: examples from the UmbriaMarche-Sabina Apennines (central Italy), Palaeogeogr. Palaeoclimatol. Palaeoecol., 184, 251-273.

Ogg, J. G. (1981), Sedimentology and paleomagnetism of Jurassic pelagic limestones: "Ammonitico Rosso" facies, Ph.D. thesis, 212 pp., Scripps Inst. of Oceanogr., Univ. of Calif., San Diego.

Ogg, J. G., M. B. Steiner, F. Oloriz, and J. M. Tavera (1984), Jurassic magnetostratigraphy, 1. Kimmeridgian-Tithonian of Sierra Gorda and Carcabuey, southern Spain, Earth Planet. Sci. Lett., 71, 147-162.

Ogg, J. G., M. B. Steiner, M. Company, and J. M. Tavera (1988), Magnetostratigraphy across the Berriasian-Valanginian stage boundary (Early Cretaceous), at Cehegin (Murcia Province, southern Spain), Earth Planet Sci. Lett., 87, 205-215.

Ogg, J. G., R. W. Hasenyager, W. A. Wimbledon, J. E. T. Channell, and T. J. Bralower (1991), Magnetostratigraphy of the Jurassic-Cretaceous boundary interval-Tethyan and English faunal realms, Cretaceous Res., $12,455-482$ 
Olivier, N., B. Pittet, and E. Mattioli (2004), Palaeoenvironmental control on sponge-reefs and contemporaneous deep-shelf marl-limestone deposition (Late Oxfordian, southern Germany), Palaeogeogr. Palaeoclimatol. Palaeoecol., 212, 233-263.

Opdyke, N. D., and J. E. T. Channell (1996), Magnetic Stratigraphy, Int. Geophys. Ser., vol. 64, 346 pp., Elsevier, New York.

Pittet, B., and E. Mattioli (2002), The carbonate signal and calcareous nannofossil distribution in an Upper Jurassic section (Balingen-Tieringen, Late Oxfordian, southern Germany), Paleogeogeogr. Paleoclimatol. Paleoecol., 179, 71-96.

Roth, P. H. (1984), Preservation of calcareous nannofossils and fine-grained carbonate particles in Mid-Cretaceous sediments from the southern Angola Basin, Initial Rep. Deep Sea Drill. Proj., 75, 651-655.

Santantonio, M. (1993), Facies association and evolution of pelagic carbonate platform/basin systems: Examples from the Italian Jurassic, Sedimentology, 40, 1039-1067.

Tarduno, J. A., W. Lowrie, W. V. Sliter, T. J. Bralower, and F. Heller (1992), Reversed polarity characteristic magnetizations in the Albian Contessa sections, Umbrian Apennines, Italy: Implications for the existence of a Mid-Cretaceous mixed polarity interval, J. Geophys. Res., 97, 241271
Tribovillard, N. P., G. Gorin, S. Belin, G. Hopfgartner, and R. Pichon (1992), Organic-rich biolaminated facies from a Kimmeridgian lagoonal environment in the French Southern Jura mountains: A way of estimating accumulation rate variations, Palaeogeogr. Palaeoclimatol. Palaeoeco., 99, $163-177$

Williams, J. R., and T. J. Bralower (1995), Nannofossil assemblage, fine fraction stable isotopes, and the paleoceanography of the ValanginianBarremian (Early Cretaceous) North Sea Basin, Paleoceanography, 10, $815-839$.

Zijderveld, J. D. A. (1967), AC demagnetization of rocks: Analysis of results, in Methods in Palaeomagnetism, edited by S. K. Runcorn, K. M. Creer, and D. W. Collinson, pp. 254-286, Elsevier, New York.

F. Calamita and S. Satolli, Dipartimento di Scienze della Terra, Università di Chieti, via dei Vestini 30, Chieti scalo, I-66013, Italy.

E. Mattioli, Centre de Sciences de la Terre, Université Claude Bernard Lyon 1, 43 boulevard du 11 Novembre 1918, F-69622 Villeurbanne, France.

F. Speranza, Istituto Nazionale di Geofisica e Vulcanologia, Roma 2, via di Vigna Murata 605, I-00143 Rome, Italy. (speranza@ingv.it) 